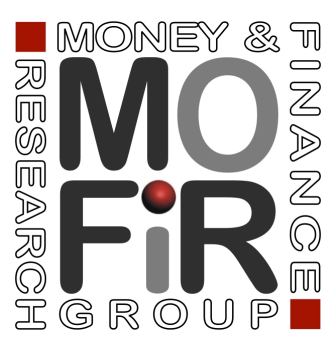

\title{
INTERNATIONAL FINANCIAL INTEGRATION OF EAST ASIA AND PACIFIC
}

Tatiana Didier Ruth Llovet Montanes

Sergio L. Schmukler

Working paper no. 139

March 2017 


\title{
International Financial Integration of East Asia and Pacific
}

\author{
Tatiana Didier
}

Ruth Llovet Montanes

February 21, 2017

\begin{abstract}
This paper provides a comprehensive analysis of how economies in the East Asia and Pacific (EAP) region have been integrating financially with the rest of the world since the 1990s, using bilateral data on portfolio investments, syndicated bank loans, mergers and acquisitions (M\&As), and greenfield investments. Four main messages emerge from the analysis. First, the region is increasingly more connected with itself and with the rest of the world, even relative to GDP. Second, although economies in the North capture the bulk of the region's inward and outward investments, EAP's connectivity with the South has grown relatively faster. Third, EAP is relatively more connected through arm's length financing (portfolio investments and syndicated loans) with the more financially developed North, and through FDI (M\&A and greenfield investments) with itself and the South. Fourth, more developed EAP economies have a larger role in EAP's arm's length investments than in the region's FDI.
\end{abstract}

JEL Classification Codes: F14; F21; F23; G15

Keywords: cross-border capital flows; foreign direct investment; international financial integration; portfolio investments; syndicated loans; trade flows

\footnotetext{
${ }^{*}$ This paper is forthcoming in the Journal of the Japanese and International Economies. We received very helpful comments from Ana Maria Aviles, Shin-Ichi Fukuda (the editor), Joao M.C. Santos Silva, Luis Serven, Nikola Spatafora, an anonymous referee, and the East Asia and Pacific (EAP) Region of the World Bank. Research support came from the World Bank's Development Economics Department, the EAP Region, the Knowledge for Change Program (KCP), and the Strategic Research Program (SRP).

Email addresses: tdidier@,worldbank.org; rllovetmontanes@,worldbank.org; $\underline{\text { sschmukler@,worldbank.org. }}$
} 


\section{Introduction}

The international financial integration of the East Asia and Pacific (EAP) region has captured significant attention in recent years. Part of this interest comes from the fact that EAP has been the region with the highest GDP growth in the world in the past decades, accounting for 29 percent of the world GDP in 2015, up from about 21 percent in 1990. As it captured a larger share of the world's income, became more developed, and deregulated its financial markets, EAP has been expected to play an increasingly larger role in international financial transactions along with the North (G7 members, excluding Japan, and 15 other Western European economies). But EAP is not alone. The increasing participation of EAP in the global economy is part of a broader trend that includes the South (non-EAP and non-North economies). Since the early 1990s, both EAP and the South have been growing faster than the North and, by now, they account for an important fraction of the world's economic and financial activity (Hanson, 2012; World Bank, 2011, 2013, 2017; UNCTAD, 2013, 2015; United Nations, 2014; WTO, 2014; de la Torre et al., 2015; Broner et al., 2016).

As part of the interest in EAP's role in the world economy, one strand of the literature has concentrated on documenting the international financial integration patterns of the region. A natural way to do it is by analyzing the geographical composition of its investments, which requires crossborder bilateral data. ${ }^{1}$ Several papers focus on the comparison of EAP's global and regional financial integration using gravity models (Eichengreen and Park, 2005a; Lee, 2008; Kim et al., 2008; GarciaHerrero et al., 2009; Borensztein and Loungani, 2011; Pongsaparn and Unteroberdoerster, 2011; Lee et al., 2013; Ananchotikul et al., 2015). This literature typically finds that EAP economies maintain stronger financial links with the rest of the world than with other economies within the EAP region. Some of these studies also benchmark EAP's intra-regional financial integration with that of Europe

\footnotetext{
${ }^{1}$ A number of papers have studied EAP's financial integration process using other alternative measures, such as prices (Eichengreen and Park, 2005b; Chi et al., 2006; Yu et al., 2010; Hinojales and Park, 2011; Boubakri and Guillaumin, 2015), correlation between domestic savings and investment rates (Guillaumin, 2009), and the degree of consumption risk-sharing (Kim et al., 2006; Ng and Yarcia, 2014).
} 
and Latin America and the Caribbean (LAC), concluding that EAP lags behind Europe whereas it is comparable to LAC. Because this literature focuses on arm's length investments (either portfolio investments or bank claims), it does not examine the differences in investment patterns across financial instruments. ${ }^{2}$

A second strand of the literature discusses the financial integration of the EAP region in an indirect way, by analyzing the financing of the U.S. current account deficit. This literature examines how several developing economies, mainly Asian and oil exporter economies, have sustained large current account surpluses and have accumulated U.S. financial assets, leading to the so-called "global imbalances" (Bernanke, 2005; Clarida, 2005; Chinn and Ito, 2007; Gruber and Kamin, 2007; Caballero et al., 2008; Cooper, 2008; Adams and Park, 2009; Caballero and Krishnamurthy, 2009; Caballero, 2010; Forbes, 2010; Obstfeld, 2012). In related work, some authors argue that the sustainability of the large U.S. deficit is linked to the fact that the U.S. earns a higher return on its foreign assets than what it pays to foreigners on its liabilities. This return differential can be attributed to the composition of the U.S. external assets and liabilities (Gourinchas and Rey, 2007; Gourinchas et al., 2012). In particular, the U.S. holds foreign direct investment (FDI) and equity as assets, whereas it has low-yield riskless liabilities (Lane and Milesi-Ferretti, 2007, 2015; Mendoza et al., 2009; Milesi-Ferretti et al., 2010; Prasad, 2011; Kubelec and Sa, 2012).

The two strands of the literature mentioned above claim that the relative financial underdevelopment of Asian economies plays an important role in their integration patterns. ${ }^{3}$ The first strand argues that Asian economies prefer to invest globally rather than regionally due to their

\footnotetext{
2 Although a couple of studies examine different financial instruments, they present only graphical evidence and do not explore for instance if the different intra-regional integration patterns across investment types are also observed in EAP's inter-regional investments (Pongsaparn and Unteroberdoerster, 2011; Ananchotikul et al., 2015).

${ }^{3}$ Financial markets in the EAP region are typically less developed than those in the North, whereas they are more developed than those in the South. For example, the share of domestic credit to the private sector over GDP was 101 percent for the average North economy during 1990 and 2014, whereas it was 70 percent and 29 percent for the average EAP and South economy, respectively. The share of nonbank financial institutions' assets over GDP was 88 percent, 27 percent, and 10 percent, for the average North, EAP, and South economy, respectively.
} 
inadequate financial and legal structure, lack of liquidity, low auditing and accounting standards, low transparency, and weak corporate governance. The second strand argues that Asian economies lack enough "safe" assets in which to allocate their excess savings and, therefore, invest in assets from developed economies. But financial underdevelopment can manifest in other forms too, with implications for the geographical composition of a country's external balance sheet. In particular, the higher degree of financial development of the North affects not only its availability of financial instruments for both domestic and foreign savers, but also the sophistication and depth of its financial markets and institutions that are able to invest abroad and diversify risk internationally. Therefore, given these disparities in the development of financial markets, we expect different integration patterns of the EAP region with the North, the South, and itself across the different investment types. Specifically, EAP can be expected to be more connected through arm's length financing with the North, and in relative terms more connected through FDI with the South and itself.

This paper contributes to the discussions in the literature by providing a comprehensive analysis of how EAP economies have been financially integrating across borders using different types of financial investments in an integrated framework. To do so, we assemble a novel dataset encompassing bilateral cross-border portfolio investments, syndicated loans, mergers and acquisitions (M\&As), and greenfield investments (the latter two jointly known as FDI) between 1990 and 2014. We then analyze EAP's connections with itself, the North, and the South. This helps us complement our understanding of where EAP stands in its financial integration process across all types of commonly used cross-border financial flows, taking into account all regions of the world. The bilateral dimension of our dataset allows us to analyze the financial integration process along the intensive margin (value of cross-border bilateral investments) and the extensive margin (number of connections/partners), as well as contrast EAP's connectivity with the North vis-à-vis the South. It 
also helps us shed light on whether financial development (and economic development more generally) might explain the broader patterns of EAP's integration.

Although the paper contains several facts about EAP's international financial integration, four main related messages emerge from the analysis and can be summarized as follows. First, the EAP region is increasingly more connected with itself and with the rest of the world in terms of portfolio investments, syndicated loans, and M\&As, even relative to GDP. Moreover, the gravity model estimates indicate that the degree of EAP's financial integration is typically greater than that of South regions along both the intensive and extensive margins.

Second, EAP's connections with the South have grown relatively faster than those with the North, due to expansions in both the intensive and the extensive margins. Nevertheless, the North remains by far the main source and destination of EAP's investments to and from the rest of the world (EAP's inter-regional investments). The EAP's intra-regional investments are of considerable size, too. In fact, they are larger than those with the South, and for some investment types they are as large as those with the North.

Third, in relative terms, EAP economies are more connected intra-regionally and with the South in FDI, whereas they are more connected with the North in arm's length investments. The differences in EAP's financial integration patterns across investment types can be related to the relatively less developed EAP's and South's financial markets vis-à-vis those of the North.

Fourth, more developed EAP economies (as measured by their GDP per capita) account for the bulk of the value of EAP's intra- and inter-regional investments, though their dominance in the process of EAP's financial integration is more subdued along the extensive margin. They also have a larger role in the region's arm's length investments (resembling integration patterns of the North), whereas less developed EAP economies have a larger participation in the region's FDI (integrating in a way similar to that of South economies). 
Taken together, our findings expand the literature on EAP's international financial integration in several ways. First, although we find that the EAP region is more financially integrated with global markets (North and South together) than with regional ones (consistent with previous research), the results change when we analyze EAP's integration with the North and the South separately. EAP's intra-regional investments are actually larger than those with the South for all investment types, whereas they are smaller than those with the North in arm's length investments but equal or greater in FDI. Second, we confirm that EAP is more intra-regionally integrated (both in terms of value and connectivity) than LAC, but we also find that this result can be generalized to the rest of South regions. Third, the heterogeneity in the level of financial development across EAP economies has important implications on the region's integration patterns. We find that the more developed EAP economies have a larger participation in EAP's arm's length investments than in EAP's FDI, whereas less developed EAP economies are more important when considering the region's FDI. Overall, our findings across types of investments, across regions, and across economies are consistent with the arguments in the literature about the effects of financial development on financial integration.

The rest of the paper is organized as follows. Section 2 describes the data. Section 3 shows the main patterns of financial integration of EAP. Section 4 formally assesses EAP's financial integration patterns with a gravity model. Section 5 focuses on the heterogeneity in patterns across EAP economies, highlighting the role played by the more developed EAP economies. Section 6 presents a benchmarking exercise of the degree of EAP's financial integration against that of the North and the South regions. Section 7 concludes.

\section{Data}

To analyze EAP's patterns of international financial integration, we assemble new data for four types of cross-border bilateral investments: portfolio investments, syndicated loans, M\&As, and greenfield 
investments. For portfolio investments, we use the Coordinated Portfolio Investment Survey (CPIS) from the International Monetary Fund (IMF) that measures the bilateral stock of portfolio assets, covering the period 2001-2014 for 75 source and 207 recipient economies. The data on cross-border syndicated loans are available at the transaction level and come from Thomson Reuters' SDC Platinum database, covering the period 1996-2014. They comprise 111 source and 183 recipient economies. For FDI, we also use transaction-level data from two different sources. For M\&As, we use Thomson Reuters' SDC Platinum. For (announced) greenfield investments, we use the Financial Times' fDi Markets. The M\&A data span the 1990-2014 period and cover 139 source and 162 recipient economies. The greenfield investment data cover the 2003-2014 period, encompassing 157 source and 193 recipient economies. $^{4}$

The different datasets are not directly comparable in terms of their overall value of international investments. The CPIS annual data are on the stock of bilateral investments, whereas all the other data are aggregated to bilateral annual flows. In particular, we aggregate the transaction-level data to the bilateral level by summing the value of all transactions from a given source economy to a given recipient economy for every year in the sample. Because of their different nature, the value of portfolio investments is considerably larger than that of syndicated loans, M\&As, and greenfield investments. Nonetheless, the overall patterns on their evolution across and within the different types of financial assets are still informative. The same applies to the comparisons of the number of connections of EAP with different regions and with itself.

To benchmark the extent of EAP's financial integration with itself and other North and South economies, we estimate a gravity model including the following control variables: the GDP of the

\footnotetext{
${ }^{4}$ North economies report consistently across the different databases, implying a good coverage of North-North and North-South connections. However, reporting of South-North and South-South transactions remains relatively sparse, arguably leading to an underestimation of the value of these connections. Because reporting by South economies varies across investment types, we also constructed graphs and computed regressions using a common sample of reporting economies. The results are qualitatively similar to the ones reported in the paper.
} 
source and the destination economies, the geographical distance between these two economies, differences in time zones, whether these economies share a common language, whether they have a common legal origin, whether they share a border, and whether there is a colonial relationship between them. ${ }^{5}$ In some regression specifications, we also include bilateral trade flows between economies, which cover the 1990-2014 period for 176 source and recipient economies. The source of the trade data is the IMF's Direction of Trade Statistics (DOTS).

We conduct the analyses in the paper for three distinct groups of economies: EAP, North, and South. The EAP region includes the following economies: American Samoa, Australia, Brunei Darussalam, Cambodia, China, Democratic People's Republic of Korea, Federated States of Micronesia, Fiji, French Polynesia, Guam, Hong Kong SAR (China), Indonesia, Japan, Kiribati, Lao People's Democratic Republic, Malaysia, Marshall Islands, Mongolia, Myanmar, Nauru, New Caledonia, New Zealand, Northern Mariana Islands, Papua New Guinea, Philippines, Republic of Korea, Singapore, Solomon Islands, Taiwan (China), Thailand, Timor-Leste, Tonga, Tuvalu, and Vietnam. The North comprises the following G-7 and Western European economies: Austria, Belgium, Canada, Denmark, Finland, France, Germany, Greece, Iceland, Ireland, Italy, Luxembourg, Netherlands, Norway, Portugal, San Marino, Spain, Sweden, Switzerland, United Kingdom, and the United States. The South includes all other economies not defined in the other two regions. We exclude from the analysis offshore financial centers as defined by the IMF. ${ }^{6}$

\footnotetext{
5 The source of all control variables at the bilateral level is CEPII's GeoDist database. The only exception is the variable on economies' common legal origin, which comes from La Porta et al. (1998). The GDP data come from the World Bank's WDI database.

${ }^{6}$ The following offshore financial centers were excluded from the analysis: Andorra, Anguilla, Aruba, Bahamas, Belize, Bermuda, British Virgin Islands, Cayman Islands, Cook Islands, Cyprus, Gibraltar, Guernsey, Isle of Man, Jersey, Liechtenstein, Macao, Monaco, Montserrat, Netherlands Antilles, Palau, Panama, Samoa, Seychelles, Turks and Caicos Islands, and Vanuatu. The list comes from https://www.imf.org/external/NP/ofca/OFCA.aspx.
} 


\section{The extent of EAP's financial integration}

In this section, we examine the degree to which EAP economies have integrated financially with economies in the North and the South (inter-regional integration) and with other EAP economies (intra-regional integration). Exploiting the bilateral nature of our dataset, we study the patterns of EAP's financial integration along the intensive margin (value of investments) and the extensive margin (number of partners/connections) for portfolio investments, syndicated loans, M\&As, and greenfield investments. We also explore whether EAP has been a net exporter or a net importer of the different types of cross-border investments.

\subsection{Inter-regional investments}

EAP economies have become increasingly more financially connected with the rest of the world (economies outside the EAP region) in terms of portfolio investments, syndicated loans, and M\&As, but not in greenfield investments. For example, the value of syndicated loans and M\&As more than doubled between 2003 and 2014 (Figure 1). In contrast, greenfield investments decreased by about 24 percent during the same period. This expansion in EAP's financial integration has not been a monotonic process. As illustrated in Figure 1, investments to and from EAP have been characterized by boom and bust patterns.

The expansion of EAP's inter-regional investments is not attributable just to the fast growth in real economic activity observed across the region. EAP's GDP increased to about 28 percent of world GDP by 2014, up from about 20 percent in 1990. As is well known, China's growth has been

particularly high: its GDP grew from around 2 percent of world GDP in 1990 to about 13 percent in 2014. Nonetheless, when financial investments are scaled by GDP, the documented patterns still hold. That is, we still observe expansions in inter-regional portfolio investments, syndicated loans, and M\&A flows to and from EAP. Naturally, greenfield investments still follow a downward-sloping trend. For 
example, after accounting for GDP growth, EAP's inter-regional portfolio investments grew at an annual average rate of 4 percent, syndicated loans grew at 8 percent, and M\&As at 10 percent, whereas greenfield investments decreased at an average rate of 7 percent during 2003 and $2014 .^{7}$

EAP has consistently been more important as a source than as a destination of investments to/from the rest of the world, a reflection of its role as a net saving region. Whereas there has been an important rise in the role played by EAP as a recipient region, outward investments from the region still outweigh its inward investments, except for greenfield investments (Figure 1). For example, EAP's outward syndicated loans to the rest of the world accounted for 73 percent of EAP's (outward and inward) inter-regional syndicated loans during the period 2003-2014. EAP's role as a sender of investments to the rest of the world was also prominent for M\&As, at 60 percent of (outward and inward) inter-regional M\&A flows during the same period. In contrast, greenfield investment flows from EAP to the rest of the world accounted for less than 50 percent of (outward and inward) interregional greenfield flows over the same period. These patterns of integration are similar to those typically observed for North economies, but markedly different from those observed for South economies. That is, South economies are usually more important as a destination rather than as a source of financial investments. North economies, on the other hand, stand as the major counterpart of these flows to the South and are thus large senders of financial investments.

Another notable feature of the EAP's financial integration with the rest of the world is that investments to and from the North are substantial, and are typically larger than those to and from the South. That is, the composition of partners in the region's inter-regional investments reveals that most of the EAP's investments to and from the rest of the world typically involve North economies. During 2003-2014, the North accounted on average for 98 percent of the value of EAP's inter-regional

\footnotetext{
${ }^{7}$ For greenfield investments, the growth rates are calculated using the 2004-2014 period because the data are available only from 2003 onward.
} 
portfolio investments, 87 percent of EAP's syndicated loans, 83 percent of EAP's M\&As, and 64 percent of EAP's greenfield investments (Figure 2). The role of the North is particularly important when EAP is a recipient rather than a sender of investments.

Although economies in the North still capture the bulk of the region's inter-regional investments, EAP's connectivity with the South has grown relatively faster. In particular, for the 20032014 period, investments to/from South economies grew at an annual average rate of 23 percent for portfolio investments, 30 percent for syndicated loans, 86 percent for M\&As, and 9 percent for greenfield investments. In contrast, cross-border investments involving North economies grew at an annual average rate of 10 percent for portfolio investments, 14 percent for syndicated loans, 17 percent for M\&As, and decreased at a 3 percent for greenfield investments. This faster growth in EAP's investments with the South has consequently led to an increased participation of these economies in EAP's inter-regional connectivity (vis-à-vis North economies). Nevertheless, as shown in Figure 2, the North has remained the principal source and destination of EAP's inter-regional investments.

Whereas the financial integration patterns described so far hold for all investment types, there exist marked differences across financial instruments. By focusing on the value of the inter-regional investments, Figure 2 indicates that EAP is relatively more connected through arm's length financing (portfolio investments and syndicated loans) with the North and through FDI (M\&As and greenfield investments) with the South. Furthermore, Figure 2 shows that these differences in EAP's integration patterns across investment types also apply to growth rates. In particular, relative to other financial investments, EAP's FDI linkages with the South have grown significantly faster than those with the North. For example, EAP's cross-border greenfield investments with the South increased at an average rate of 9 percent during 2003-2014 vis-à-vis the average 3 percent decline with the North. The average growth of the South for M\&As was 5 times larger than the growth of the North. The 
differences for portfolio investments and syndicated loans are a bit less stark: the growth of the South was 2 times larger than the one experienced by the North.

The growth in financial investments between EAP and the South can be traced to expansions not only in the value of their financial connections (intensive margin), as described above, but also in the number of active connections (extensive margin). This expansion along the extensive margin can be clearly seen in the maps in Figure 3, which depict all positive bilateral connections between EAP and the South. These maps show visually an increase in the number of financial linkages for all four types of financial investments, though the increase in connectivity for greenfield investments is arguably less marked as EAP was already well connected at the beginning of the sample period. As an example of EAP's increased financial linkages with the South, consider mainland China. It has connected with 21 new South economies through portfolio investments between 2001 and 2014, 25 new economies through syndicated loans between 1996-1998 and 2012-2014, 21 new economies through M\&As between 1990-1992 and 2012-2014, and 35 new economies through greenfield investments between 2003-2005 and 2012-2014. Among these new connections for China, some are common to all investment types such as Slovakia and Mauritius. Similarly, over the same sample periods considered above, the Republic of Korea connected with 36 new South economies in portfolio investments, 8 in syndicated loans, 14 in M\&As, and 32 in greenfield investments.

\subsection{Intra-regional investments}

EAP economies have also become increasingly more connected with other economies within the EAP region. Cross-border portfolio investments, syndicated loans, and M\&As have all increased substantially within the EAP region. Moreover, the growth of EAP's intra-regional investments cannot be fully explained by the fast growth of the region's real economic activity. All investment types grow at a positive rate even after accounting for the GDP, except for greenfield investments. 
Intra-regional investments have increased in both the intensive and the extensive margins. For example, the value of EAP's intra-regional financial investments in 2014 was 3 times larger than in 2003 for portfolio investments, 4 times larger for syndicated loans, and 6 times larger for M\&As, whereas it was 12 percent smaller for greenfield annual flows (Figure 4). There has also been some growth along the extensive margin, though more subdued, especially in greenfield investments as EAP was already well connected intra-regionally at the beginning of the sample period (Figure 5). For example, when comparing the number of active financial connections at the beginning and at the end of each financial investment's sample period, Mongolia connected with 8 new EAP economies through portfolio investments, 3 through syndicated loans, 3 through M\&As, and 5 through greenfield investments. ${ }^{8}$ Among these new connections for Mongolia, some are common to all investment types, such as Australia. Similarly, Vietnam connected with 2 new EAP economies in portfolio investments, 3 in syndicated loans, 10 in M\&As, and 3 in greenfield investments.

Although not tested formally in this paper, this trend of increased connectivity in cross-border financial investments within EAP could be associated, at least in part, with the rise of investment agreements implemented within the region. ${ }^{9}$ That is, as economies liberalized their de jure restrictions on investment flows, de facto integration has arguably grown as well. For instance, the Association of Southeast Asian Nations (ASEAN) launched the ASEAN Comprehensive Investment Agreement (ACIA), which came into effect on March 2012. The main objective of the ACIA is to boost withinASEAN cross-border investments by establishing a free, open, transparent, and integrated investment

\footnotetext{
8 The sample periods that are compared for each investment type are 2001 vs. 2014 for portfolio investments, 1996-1998 vs. 2012-2014 for syndicated loans, 1990-1992 vs. 2012-2014 for M\&As, and 2003-2005 vs. 2012-2014 for greenfield investments.

${ }_{9}^{9}$ More generally, EAPs policymakers have placed fostering financial integration high on their agendas with the belief that more investments, not only within EAP economies but also with other regions, would be beneficial for the region's economic growth. Evidence of this policy priority is the existence of 107 bilateral investment treaties (BITs) that involve mainland China, 69 BITs involving India, and 49 BITs involving Malaysia.
} 
regime for domestic and international investors throughout the ASEAN member states. ${ }^{10}$ Moreover, stock exchanges from Indonesia, Malaysia, Philippines, Singapore, Thailand, and Vietnam have been working together to form the ASEAN Exchanges, aiming to promote ASEAN capital market integration. This collaboration created the ASEAN Trading Link on September 2012, a network that connects the region's stock markets, making it easier for investors inside and outside the ASEAN region to trade stocks listed on their stock markets.

In addition, there are a number of other financial cooperation initiatives aimed at fostering intra-regional integration, including the Chiang Mai Initiative, the ASEAN Capital Market Forum (ACMF), and the Asian Bond Markets Initiative (ABMI). The Chiang Mai Initiative, launched in 2010, aims to create a network of bilateral swap arrangements among the ASEAN economies, the People's Republic of China (including Hong Kong SAR, China), Japan, and the Republic of Korea to address short-term liquidity problems in the region and to complement the existing international financial arrangements. The ACMF, established in 2004, is a forum comprising capital market regulators from 10 ASEAN jurisdictions (Brunei Darussalam, Cambodia, Indonesia, Lao PDR, Malaysia, Myanmar, Philippines, Singapore, Thailand, and Vietnam). It initially focused on projects to harmonize standards in capital market regulations, but it has since shifted toward more strategic issues to achieve greater integration of the region's capital markets. The ABMI, launched in 2003, aims at developing localcurrency denominated bond markets and a more accessible and well-functioning regional bond markets both for issuers and investors by improving the regulatory framework.

\footnotetext{
10 According to ASEAN, ACIA aims to enhance protection to investors and their investments, promote the ASEAN region as an integrated investment area that has favorable conditions for domestic and international investment, improve the transparency and predictability of investment rules, and achieve a free and open investment environment through progressive investment liberalization.
} 


\subsection{Inter-regional vs. intra-regional investments}

Despite its sizeable share in total EAP's cross-border investments (considering investments with the North, the South, and with itself), intra-regional investments are on average smaller in size than interregional investments. But EAP's intra-regional investments are larger than those with the South and, for some investment types, they are as large as (if not larger than) those involving North economies. For example, EAP's intra-regional investments and investments with the South accounted for about 24 percent and 2 percent of EAP's total cross-border portfolio investments in 2014, respectively (Figure 6). EAP's investments with the North captured the rest, about 74 percent. Similar shares are observed for syndicated loans. Regarding FDI, EAP's intra-regional investments and EAP's investments with the South represented on average 44 percent and 10 percent of total cross-border M\&A flows, respectively, for the 2003-2014 period, and 48 and 19 percent of total cross-border greenfield investments during the same period. Note that, akin to the trends described in Section 3.1, the share of EAP's intra-regional investments and investments with South tends to be greater in FDI than in arm's length investments.

Regarding the evolution of these shares over time, intra-regional investments grew on average faster than their respective inter-regional counterparts for all investment types during 2003-2014. Intra-regional investments also grew faster than investments with the North, though they grew slower than investments with the South. These trends suggest that EAP's investments with the South have been catching up with intra-regional investments over time.

\section{A gravity model of EAP's cross-border investments}

Next, we analyze more formally the region's financial integration patterns documented thus far. Specifically, we estimate a gravity model using the Poisson Pseudo-Maximum-Likelihood (PPML) 
estimator proposed by Santos Silva and Tenreyro (2006). ${ }^{11}$ We focus on a specification in which the dependent variable is the value of a certain cross-border financial investment between a pair of economies; the explanatory variables are a set of region-pair dummies (EAP-North, EAP-South, North-EAP, South-EAP, and EAP-EAP) and a set of standard gravity model controls, as described in Section 2. ${ }^{12}$ Table 1 reports the estimation results, as well as two-tailed Wald tests for differences between some of the coefficients. ${ }^{13}$

Overall, the results corroborate the graphical evidence presented earlier. The estimations show that, even after controlling for the source and recipient's GDPs and the other gravity variables, EAP's investments to and from the North are significantly larger than those to and from the South. Moreover, the estimations indicate that this difference in the value of cross-border investments with the North and South is arguably larger in arm's length investments than in FDI, especially in greenfield investments. ${ }^{14}$ The results also show that EAP's intra-regional investments are always greater than those with the South. In contrast, EAP's intra-regional investments are smaller than portfolio investments and syndicated loans with the North, but significantly larger than M\&As and greenfield

\footnotetext{
${ }^{11}$ Perhaps the most popular approach in the trade literature is to log-linearize the gravity model and estimate the parameters of interest using Ordinary Least Squares (OLS). However, this log-linearization approach is problematic when the data have many zero-value observations. For instance, selection bias may be an issue if zeros are not randomly distributed. Addressing this issue, Santos Silva and Tenreyro (2006) argue that under the presence of heteroskedasticity, the OLS can lead to biases in the estimation of the true elasticities. They propose the PPML estimator to deal with these potential biases. 12 Only investments involving EAP economies are considered in the analysis. All other observations are dropped. For example, investments between the U.S. and Japan are included in the analysis, but investments between the U.S. and Argentina are excluded from the estimations.

13 Although the time span varies across the different databases analyzed here, we estimate all the regressions for the 20032014 period to facilitate a comparison across the different investment types. As a robustness check, we estimate these regressions using the full sample period of every dataset. Another robustness check on the reported estimations relates to the varying country coverage across investment types. Specifically, we estimate the regressions using a common group of reporting economies across all datasets. The results of all these robustness estimations are qualitatively similar to the ones reported here and available upon request.

${ }^{14}$ In additional non-reported tests, we estimate the same gravity model considered in Table 1 in a multivariate setup that allows to make inference about the estimated coefficients across the different investment types. Specifically, we estimate cross-equation Wald tests on a linear model using the log of value of a certain cross-border financial investment between a pair of economies as the dependent variable. The results of these tests indeed indicate that the difference between EAP's investments sent to and received from the North (relative to those of the South) are significantly larger in portfolio investments and syndicated loans than in M\&A and greenfield investments. These estimations are available upon request.
} 
investments with the North. These patterns hold for EAP economies as both senders and recipients of cross-border financial investments.

The estimated coefficients on the gravity controls are in line with existing estimations in the literature. They show that the magnitude of cross-border financial connections between two economies increases with their size (proxied by GDP), when they share a common legal origin, language, and when they have a common border.

Beyond the standard gravity controls, the literature also identifies cross-border trade in goods as an important factor potentially affecting cross-border financial investments. Empirical studies seem to support the idea of complementarity between trade and finance. ${ }^{15}$ For instance, a number of studies estimate gravity models to show that economies' financial portfolios are strongly tilted toward their trading partners (Portes and Rey, 2005; Aviat and Coeurdacier, 2007; Daude and Fratzscher, 2008; Lane and Milesi-Ferretti, 2008; Dailami et al., 2012). Therefore, for robustness, we also include in our estimated regressions the logarithm of exports as an additional control. ${ }^{16}$ The results are also reported in Table 1.

Importantly, the patterns of EAP's financial integration and the differences across investment partners and across investment types reported so far still hold when bilateral trade is included in the estimations. Moreover, the estimations also show that there is a statistically significant positive correlation between bilateral trade and bilateral investments, which is especially strong for FDI. For instance, a 10 percent increase in trade between two economies is associated with a 4 percent increase in M\&A and greenfield flows between those economies.

\footnotetext{
15 The theoretical literature, however, is not conclusive on whether cross-border financial investments are trade replacing or trade creating (Mundell, 1957; Markusen, 1983; Antras and Caballero, 2009; Ju and Wei, 2011; Jin, 2012). Several papers point out that the complementarity or substitution between cross-border trade and finance arguably depends on the sector considered. See for example, Swenson (2004) and Chiappini (2016).

${ }^{16}$ In the regressions, we measure bilateral trade through exports because financial investments are also measured only in one direction (the asset side).
} 
This complementarity in trade and finance found in the data for the EAP region suggests that the implementation of trade agreements could promote not only cross-border trade but also crossborder investment growth. Hence, EAP's financial investments might have grown not only due to the aforementioned investment agreements, but also due to trade agreements such as the ASEAN Free Trade Agreement (AFTA), signed in 1992. The AFTA aims to increase trade integration among Asian economies by lowering intra-regional tariffs through the Common Effective Preferential Tariff scheme (CEPT).

\section{Heterogeneity across EAP economies}

The EAP region comprises a wide range of different economies. For instance, at the extremes, Australia’s GDP per capita was 61,166 U.S. dollars in 2014, whereas Cambodia's was 1,096 U.S. dollars in the same year. Similar disparities are observed regarding the extent of their financial development. As an example, equity market capitalization of domestic companies was 1,110 percent of Hong Kong's GDP in 2014, but it was only 25 percent in the case of Vietnam. In this section, we examine the extent to which the financial integration patterns described so far vary across EAP economies.

Not surprisingly, the most developed economies in the EAP region (as measured by their per capita GDP) account for the bulk of the value of EAP's inter-regional and intra-regional investments (Figure 7). For instance, the group comprised of Japan, Australia, New Zealand, and the Newly Industrialized Economies (NIEs) (Republic of Korea; Singapore; Hong Kong SAR, China; and Taiwan, China) accounted for 90 percent of EAP's inter-regional portfolio investments in 2014. They also represented large shares of EAP's intra-regional investments, with for example 75 percent of the value of EAP's intra-regional syndicated loans over 2003-2014. Japan stands out as a major economy in the region regarding the value of EAP's inter-regional investments, whereas Hong Kong SAR (China) does so in the value of EAP's intra-regional investments. 
These more developed EAP economies have a pattern of financial integration that resembles that of the North, and as a consequence have a larger participation in EAP's arm's length financing. In contrast, the less developed EAP economies have an integration pattern similar to that observed for the South, where FDI financing is more prevalent. For example, the share of the more developed EAP economies in inter-regional syndicated loans was 92 percent, whereas it was only 47 percent for inter-regional greenfield investments for the period from 2003 to 2014 . The rest was captured by the less developed EAP economies. Similarly, the more developed EAP economies accounted for 71 percent of EAP's intra-regional investments in portfolio assets, but only 49 percent in intra-regional greenfield investments.

Although the more developed economies in the region play a major role in the process of financial integration along the intensive margin, their dominance is much smaller along the extensive margin. That is, there is not as much heterogeneity across EAP economies in terms of their connectivity. For instance, the ASEAN-5 economies (comprising Indonesia, Malaysia, Philippines, Thailand, and Vietnam) are a relatively homogeneous group, with relatively small cross-border investments when contrasted to the more advanced economies in the region, but they are relatively well connected. Their participation in the number of EAP's active connections is actually comparable to that of the NIEs. Consider also (mainland) China; its share in the number of active cross-border connections is as large or even greater than that of Japan in syndicated loans, M\&As, and greenfield investments. Similarly, the remaining EAP economies have greater representativeness along the extensive rather than along the intensive margin of the region's financial integration process. Nonetheless, the overall extent of financial integration of these economies is more limited along both margins when compared with the other EAP economies. 


\section{Benchmarking EAP's cross-border investments}

As discussed in the Introduction, the literature has emphasized that developing economies have been gaining space in global finance and, since the 2000s, have become a significant source and destination of FDI, bank lending, and portfolio investments. ${ }^{17}$ For example, whereas South economies received about $9 \%$ of global capital inflows in 1990, by 2012 they received 33\% of total world flows. As sources of capital flows, South economies sent about $34 \%$ of global capital outflows by 2012 , up from $12 \%$ in 1990. Importantly, South economies have broadened and deepened their connections not only with the North, but also with other South economies. The patterns of EAP's financial integration shown in the previous sections suggest that the region has followed these overall trends for the South, but little else is known about the role that EAP economies have played in this new phase of financial globalization. Thus, in this section, we expand the existing evidence by benchmarking EAP against both North and South regions and test how EAP has been integrating financially with itself and with the rest of the world.

To benchmark EAP's cross-border financial investments, we estimate a gravity model similar to that in Section 4. In particular, we estimate three specifications assessing EAP's intra- and interregional financial connectivity, both from the sender and the recipient point of view, using the PPML estimator described earlier. In all specifications, the dependent variable is the value of a certain crossborder financial investment between a pair of economies. The explanatory variables are intra-regional dummies (when benchmarking intra-regional investments) or inter-regional dummies (when benchmarking inter-regional investments). Intra-regional (inter-regional) dummies take the value of one whenever both sender and recipient economies belong to the same (different) region, and zero otherwise. These dummies are individually defined for each of the seven geographical regions

\footnotetext{
17 See, for example, Aykut and Ratha (2003), World Bank (2011 and 2013), de la Torre et al. (2015), and Broner et al.
} (2016). 
identified in our sample. ${ }^{18}$ The specifications also include the same standard gravity model controls described in Section $2 .^{19}$

Table 2 presents the results aimed at evaluating whether EAP economies are more (or less) integrated than North and South economies. It reports separately the benchmarking exercise associated with intra-regional, outward, and inward cross-border investments. To simplify the reported table, instead of showing the estimated coefficients themselves, we present only the differences in the estimated coefficients and the associated significance of a two-tailed Wald test for these differences.

The results show that, even after controlling for source and recipient's GDPs and the other controls at the bilateral level, intra-regional investments are the largest for economies within the EAP region when contrasted with South regions. Regarding inter-regional outward investments, EAP is also ahead of all South regions. However, EAP lags behind South regions as a destination of some types of financial investments from the rest of the world. As a recipient region, EAP is ranked after the LAC region and Europe and Central Asia (ECA) for syndicated loans and M\&As, whereas it is comparable to the other South regions regarding the value of its portfolio and greenfield investments. Comparisons with North economies reveal more mixed patterns across all investment types. For example, EAP has a greater degree of intra-regional and inter-regional inward greenfield investments than the North, but it lags behind on inter-regional outward greenfield investments. Regarding portfolio investments, it has relatively smaller intra-regional investments than the North, though comparable inter-regional ones.

\footnotetext{
18 For example, the EAP-EAP dummy is equal to one whenever an observation includes an EAP economy as a sender and an EAP economy as a recipient of financial investments - a connection between China and Thailand is considered an EAP intra-regional connection. An inter-regional EAP dummy takes the value one whenever there is a connection between an EAP economy and an economy outside the EAP region, such as a connection between China and the United States. There are two types of EAP inter-regional dummies because EAP economies may be either senders or recipients of international investments to and from the rest of the world.

19 Although we do not include bilateral trade as a control variable in the reported regressions, the results are qualitatively similar when we include the logarithm of exports.
} 
Similarly, we benchmark the growth over time by including in the regressions a time trend and interacting it with the inter- and intra-regional dummies. Results indicate that there are no observed trends toward reversals in the patterns described above (Appendix Table 1). That is, the differences between EAP and South regions regarding their degree of financial integration do not seem to be shrinking over time. For example, South regions have not consistently shown signs of catching up to the level of EAP's intra-regional investments.

We conduct a similar analysis to benchmark the extensive margin of EAP's financial integration. The dependent variable in these regressions is an indicator variable that takes the value one whenever there is a bilateral positive investment between a pair of economies, and zero otherwise. The explanatory variables remain the same as the ones used for the intensive margin analysis. Due to the binary nature of the dependent variable, the estimation method used in this case is the Linear Probability Model (LPM). The results are reported in Table 3.

The estimations show that EAP is ahead of South regions in its overall connectivity, with a greater degree of both intra- and inter-regional financial integration along the extensive margin. As a recipient of investments from the rest of the world, despite EAP being relatively smaller in the size of its inward investments compared to South regions (as shown by the intensive margin results), it is relatively well connected. The number of EAP's inter-regional outward connections is also significantly larger than that of the South regions. However, EAP economies lag behind North economies regarding the extent of their intra-regional and inter-regional outward connectivity. Estimations for the interaction terms with time trends do not suggest a change in these patterns over time, and if anything, they seem to have strengthened, except for portfolio investments (Appendix Table 2). 


\section{Conclusions}

Using different types of bilateral data that reflect international financial transactions (cross-border portfolio investments, syndicated bank loans, M\&As, and greenfield investments), this paper offers a comprehensive and systematic account of how economies in the EAP region have integrated with the rest of the world since the 1990s. The paper shows, first, that EAP is increasingly more connected internationally, both with itself and with the rest of the world. Second, despite being relatively less important, EAP's integration with the South has grown faster than that with the North. Third, EAP's connections with the North involve more arm's length financing than those with itself and the South, where FDI matters more. Fourth, there is significant heterogeneity in the financial connections of EAP. The more developed EAP economies integrate in a way that is similar to that of the North (with a larger role in EAP's arm's length financing), whereas less developed EAP economies integrate more similarly to South economies (with a larger participation in EAP's FDI financing).

The broad set of stylized facts presented in this paper leads to some conclusions and conjectures that could be of relevance for researchers and policy makers interested in the EAP region and in cross-border financial integration patterns more broadly. Here we highlight a few.

The findings we uncover, related to the different patterns of integration with the North and the South and across different economies in EAP, are consistent with arguments in the literature that state that financial development has an important role in international financial transactions and in how EAP has engaged financially across borders. That is, whereas other factors are surely at play, the sophistication of financial markets as economies become richer might well explain the patterns we find. Two aspects of financial development can matter. One is the availability of financial instruments that allow savers to invest and lowers the costs and risks of those investments. This might prompt EAP economies (in particular the less developed ones) to invest in securities or conduct transactions

with banks in the North. The other one is the availability of more sophisticated financial institutions 
in the North that diversify risk internationally more broadly. For example, as is well known, economies such as the United Kingdom and the Unites States have large pools of institutional investors that invest around the world, including EAP and South economies. The same applies to global banks located in developed economies. In contrast, less developed economies invest in financial assets in the North, and much more rarely in other less developed economies. For example, it would be difficult to identify mutual funds from emerging economies purchasing assets from their peers. And global banks in developing economies have appeared only in recent years (Claessens, 2016).

A number of other features of the financial integration of EAP deserve attention going forward. One is the large size of EAP's intra-regional investments relative to South regions, which suggests that there might be some benefits from international investments across economies in the region. These could be related to greater risk-sharing, a more efficient resource allocation, access to a wider range of investment projects, technology spillovers, and better governance within the region. Nonetheless, it could also bring imported volatility. One remaining question is why intra-regional integration is high and whether the same effects that intra-regional investments generate might occur with inter-regional connections.

Another issue worth studying more is the complementarity between trade and financial flows. In particular, it would be useful to understand the causality between these flows and to what extent common factors explain it. To the extent that trade is an important force behind the dynamics of EAP's cross-border investments and that EAP is becoming more connected through trade, we might expect a deepening of its financial connections. Moreover, little is known about the sectoral allocation of capital across borders and how that is related to the sectoral composition of international trade. On the one hand, EAP economies could be investing in the same sectors that they export goods because of their comparative advantage or greater expertise. On the other hand, EAP economies could be investing in sectors in which the host economy has some comparative advantage in order to reap the 
benefits of technology and learning spillovers. Moreover, EAP economies could also be investing in sectors from which they import goods, with the intention to acquire and secure resources (as many have argued to be China's strategy of investing in resource-rich African economies). ${ }^{20}$ EAP economies might also be investing abroad to hedge and/or diversify the risk of their exports (hence, mitigating possible terms-of-trade shocks). Besides the sectoral composition of trade and finance, further analysis could also inform whether foreign investments reinforce or loosen the existing comparative advantage forces observed in trade flows.

Although not discussed in detail in this paper, another aspect that deserves more research is the fact that EAP has sent more investments than it has received from the rest of the world. This pattern has generated on average positive net outward investments (except for greenfield investments). It could be interpreted as the counterpart to the persistent current account surpluses run over the years by many economies in the region, which has allowed them to invest those surpluses abroad. The large savings rate of some EAP economies might be important for economies in the region to act as the average developed economy is expected to do in theoretical predictions, exporting capital to other regions (Lucas, 1990). Moreover, the large increase in the investments that EAP has in South economies could be a sign of EAP's strategy for diversification of its large pool of international reserve assets away from developed economies. This diversification does not need to be generated from central governments. The economy as a whole might be more willing to hold other types of assets or to diversify risk by investing in economies in the South. For example, as mentioned above, evidence suggests that China (partly through state-owned enterprises) has been investing in other regions. These types of flows are indeed captured by our data.

\footnotetext{
20 See, for example, Tull (2006), World Bank (2007, 2009), Besada et al. (2008), Gu (2009), Kaplinsky and Morris (2009), Christensen (2010), Klaver and Trebilcock (2011), Kolstad and Wiig (2011), Cheung et al. (2012), Ayodele and Sotola (2014), Shen (2015), and Chen et al. (2016).
} 
The findings in this paper suggest that, as EAP continues growing and becoming richer, its patterns of financial integration will resemble more those of the North, with less relative emphasis on FDI and more on portfolio and bank investments. Moreover, as the South is also growing relatively faster, EAP is expected to be more connected with it, especially given that the South is still relatively small in international financial transactions and that the connections between EAP and the South have already been established. The growth then might happen along the intensive margin, with the value of cross-border investments growing. This, of course, has implications for the level of risk diversification and for the transmission of shocks across economies. Moreover, it will raise new questions about how to regulate the financial system and international transactions as the patterns of financial integration evolve. 


\section{References}

Adams, C. and D. Park, 2009. "Causes and Consequences of Global Imbalances: Perspective from Developing Asia," Asian Development Review 26(1), 19-47.

Ananchotikul, N., S. Piao, and E. Zoli, 2015. "Drivers of Financial Integration: Implications for Asia," IMF Working Paper 15/160.

Antras, P. and R. Caballero, 2009. "Trade and Capital Flows: A Financial Frictions Perspective," Journal of Political Economy 117(4), 701-744.

Aviat, A. and N. Coeurdacier, 2007. "The Geography of Trade in Goods and Asset Holdings," Journal of International Economics 71(1), 22-51.

Aykut, D. and D. Ratha, 2003. "South-South FDI Flows: How Big Are They?" Transactional Corporations 13(1), 149-176.

Ayodele, T. and O. Sotola, 2014. "China in Africa: An Evaluation of Chinese Investment," Initiative for Public Policy analysis (IPPA) Working Paper.

Bernanke, B., 2005. "The Global Saving Glut and the U.S. Current Account Deficit," Sandridge Lecture, Virginia Association of Economics, Richmond, VA.

Besada, H., Y. Wong, and J. Whalley, 2008. "China's Growing Economic Activity in Africa," NBER Working Papers 14024.

Borensztein, E. and P. Loungani, 2011. “Asian Financial Integration: Trends and Interruptions,” IMF Working Paper 11/4.

Boubakri, S. and C. Guillaumin, 2015. "Regional Integration of the East Asian Stock Markets: An Empirical Assessment," Journal of International Money and Finance 57, 136-160.

Broner, F., T. Didier, S. Schmukler, and G. Von Peter, 2016. "Global Capital Flows: The Big Sur?” World Bank Working Paper.

Caballero, R., E. Farhi, and P-O. Gourinchas, 2008. “An Equilibrium Model of 'Global Imbalances' and Low Interest Rates," American Economic Review 98(1), 358-393.

Caballero, R. and A. Krishnamurthy, 2009. "Global Imbalances and Financial Fragility?” American Economic Review 99(2), 584-588.

Caballero, R., 2010. “The 'Other' Imbalance and the Financial Crisis," NBER Working Papers 15636.

Chen, W., D. Dollar, and H. Tang, 2016. "Why is China Investing in Africa? Evidence from the Firm Level," The World Bank Economic Review, forthcoming.

Cheung, Y-W., J. de Haan, X. Qian, and S. Yu, 2012. "China's Outward Direct Investment in Africa," Review of International Economics 20(2), 201-220.

Chi, J., K. Li, and M. Young, 2006. "Financial Integration in East Asian Equity Markets," Pacific Economic Review 11(4), 513-525.

Chiappini, R., 2016. "Do Overseas Investments Create or Replace Trade? New Insights from a MacroSectoral Study on Japan," The Journal of International Trade \& Economic Development: An International and Comparative Review 25(3), 403-425.

Chinn, M. and H. Ito, 2007. "Current Account Balances, Financial Development and Institutions: Assaying the World 'Saving Glut'," Journal of International Money and Finance 26(4), 546-569.

Christensen, B., 2010. "China in Africa: A Macroeconomic Perspective," Center for Global Development Working Paper 230.

Claessens, S., 2016. "Global Banking: Recent Developments and Insights from Research," Review of Finance, forthcoming.

Clarida, R., 2005. "Japan, China, and the U.S. Current Account Deficit," Cato Journal 25(1), 111-114.

Cooper, R., 2008. "Global Imbalances: Globalization, Demography and Sustainability," Journal of Economic Perspectives 22(3), 93-112. 
Dailami, M., S. Kurlat and J. Lim, 2012. "Bilateral M\&A Activity from the Global South," The North American Journal of Economics and Finance 23(3), 345-364.

Daude, C. and M. Fratzscher, 2008. "The Pecking Order of Cross-border Investment," Journal of International Economics 74(1), 94-119.

De la Torre, A., T. Didier, A. Ize, D. Lederman, and S. Schmukler, 2015. Latin America and the Rising South: Changing World, Changing Priorities. World Bank.

Eichengreen, B. and Y. Park, 2005a. "Why Has There Been Less Regional Integration in East Asia than in Europe?" Chapter 4 in: A New Financial Market Structure for East Asia, Edward Elgar Publishing.

Eichengreen, B. and Y. Park, 2005b. "Financial Liberalization and Capital Market Integration in East Asia," Chapter 3 in: A New Financial Market Structure for East Asia, Edward Elgar Publishing.

Forbes, K., 2010. "Why Do Foreigners Invest in the United States?" Journal of International Economics 80, 3-21.

García-Herrero, A., P. Wooldridge, and D. Yang, 2009. "Why Don't Asians Invest in Asia? The Determinant of Cross-border Portfolio Holdings," Asian Economic Papers 8(3), 228-246.

Gourinchas, P-O. and H. Rey, 2007. "From World Banker to World Venture Capitalist: U.S. External Adjustment and the Exorbitant Privilege," Chapter 1 in: G7 Current Account Imbalances: Sustainability and Adjustment, 11-66, edited by R. Clarida, University of Chicago Press.

Gourinchas, P-O., H. Rey, and K. Truempler, 2012. "The Financial Crisis and the Geography of Wealth Transfers," Journal of International Economics 88, 266-283.

Gruber, J.W. and S.B. Kamin, 2007. "Explaining the Global Pattern of Current Account Imbalances," Journal of International Money and Finance 26(4), 500-522.

Gu, J., 2009. "China's Private Enterprises in Africa and the Implications for African Development," European Journal of Development Research 21, 570-587.

Guillaumin, C., 2009. "Financial Integration in East Asia: Evidence from Panel Unit Root and Panel Cointegration Tests," Journal of Asian Economics 20(3), 314-326.

Hanson, G., 2012. "The Rise of Middle Kingdoms: Emerging Economies in Global Trade," Journal of Economic Perspectives 26(2), 41-64.

Hinojales, M. and C-Y. Park, 2011. "Stock Market Integration: Emerging East Asia’s Experience" Chapter 7 in: The Dynamics of Asian Financial Integration: Facts and Analytics, edited by M. Devereux, P. Lane, C-Y. Park, and S-J Wei, Asian Development Bank.

Jin, K., 2012. "Industrial Structure and Capital Flows," American Economic Review 102(5), 2111-2146.

Ju, J. and S.J. Wei, 2011. "When is Quality of Financial System a Source of Comparative Advantage?" Journal of International Economics 84(2), 178-187.

Kaplinsky, R. and M. Morris, 2009. "Chinese FDI in Sub-Saharan Africa: Engaging with Large Dragons," European Journal of Development Research 21, 551-569.

Kim, S., S.H. Kim, and Y. Wang, 2006. "Financial Integration and Consumption Risk Sharing in East Asia," Japan and the World Economy 18(2), 143-157.

Kim, S., J-W. Lee, and K. Shin, 2008. "Regional and Global Financial Integration in East Asia," Chapter 7 in: China, Asia, and the New World Economy, edited by B. Eichengreen, Y. Park, and C. Wyplosz, Oxford University Press.

Klaver, M. and M. Trebilcock, 2011. "Chinese Investment in Africa," Law and Development Review 4(1), 168-217.

Kolstad, I. and A. Wiig, 2011. "Better the Devil You Know? Chinese Foreign Direct Investment in Africa," Journal of African Business 12(1), 31-50.

Kubelec, C., and F. Sa, 2012. "The Geographical Composition of National External Balance Sheets: 1980-2005, ” International Journal of Central Banking 8(2), 143-189. 
La Porta, R., F. Lopez-de-Silanes, A. Shleifer, and R.W. Vishny, 1998. "Law and Finance," Journal of Political Economy 106(6), 1113-1155.

Lane, P. and G.M. Milesi-Ferretti, 2007. "A Global Perspective on External Positions," Chapter 2 in: G7 Current Account Imbalances: Sustainability and Adjustment, 11-66, edited by R. Clarida, University of Chicago Press.

Lane, P. and G.M. Milesi-Ferretti, 2008. "International Investment Patterns," Review of Economics and Statistics 90 (3), 538-549.

Lane, P. and G.M. Milesi-Ferretti, 2015. "Global Imbalances and External Adjustment After the Crisis," Chapter 2 in: Global Liquidity, Spillovers to Emerging Markets and Policy Responses 20(1), 105-142, edited by C. Raddatz, D. Savaria, and J. Ventura, Central Bank of Chile.

Lee, H-H., H. Huh, and D. Park, 2013. "Financial Integration in East Asia: An Empirical Investigation," The World Economy 36(4), 396-418.

Lucas, R., 1990. "Why Doesn't Capital Flow from Rich to Poor Countries?” American Economic Review 80(2), 92-96.

Markusen, J., 1983. "Factor Movements and Commodity Trade as Complements," Journal of International Economics 14(3-4), 341-356.

Mendoza, E., V. Quadrini, and J-V. Ríos-Rull, 2009. "Financial Integration, Financial Development, and Global Imbalances," Journal of Political Economy 117(3), 371-416.

Milesi-Ferretti, G.M., N. Tamirisa, and F. Strobbe, 2010. "Bilateral Financial Linkages and Global Imbalances: A View on the Eve of the Financial Crisis," IMF Working Paper 10/257.

Mundell, R., 1957. "International Trade and Factor Mobility," American Economic Review 47(3), 321325.

Ng, T.H. and D.L. Yarcia, 2014. "Has Regional Integration Led to Greater Risk-sharing in Asia?" ADB Working Paper 135.

Obstfeld, M., 2012. "Financial Flows, Financial Crises, and Global Imbalances," Journal of International Money and Finance 31(3), 469-480.

Pongsaparn, R. and O. Unteroberdoerster, 2011. "Financial Integration and Rebalancing in Asia," IMF Working Paper 11/243.

Portes, R. and H. Rey, 2005. “The Determinants of Cross-Border Equity Flows," Journal of International Economics 65(2), 269-296.

Prasad, E., 2011. "Role Reversal in Global Finance," Proceedings - Economic Policy Symposium - Jackson Hole, Federal Reserve Bank of Kansas City, 339-390.

Santos Silva, J.M.C. and S. Tenreyro, 2006. "The Log of Gravity," The Review of Economics and Statistics, MIT Press 88(4), 641-658.

Shen, X., 2015. "Chinese Investment in Africa: Myths and Realities," Development Policy Review 33(1), 83-106.

Swenson, D., 2004. "Foreign Investment and the Mediation of Trade Flows," Review of International Economics 12(4), 609-629.

Tull, D., 2006. "China’s Engagement in Africa: Scope, Significance, and Consequences," Journal of Modern African Studies 44(3), 459-479.

UNCTAD, 2013. Global Value Chains: Investment and Trade for Development. World Investment Report.

UNCTAD, 2015. Key Statistics and Trends in International Trade 2014. United Nations Conference on Trade and Development.

United Nations, 2014. World Economic Situation and Prospects 2014.

World Bank, 2007. Africa's Silk Road: China and India's New Economic Frontier.

World Bank, 2009. Building Bridges: China's Growing Role as Infrastructure Financier for SubSaharan Africa. 
World Bank, 2011. Global Development Horizons: Multipolarity - The New Global Economy.

World Bank, 2013. Global Development Horizons: Capital for the Future - Saving and Investment in an Interdependent World.

World Bank, 2017. Global Financial Development Report: Global Banking.

WTO, 2014. World Trade 2014. Trade and Development: Recent Trends and the Role of the WTO. Yu, I., L. Fung, and C. Tam, 2010. "Assessing Financial Market Integration in Asia-equity Markets," Journal of Banking and Finance 34(12), 2874-2885. 
Figure 1. EAP's Inter-regional Financial Investments
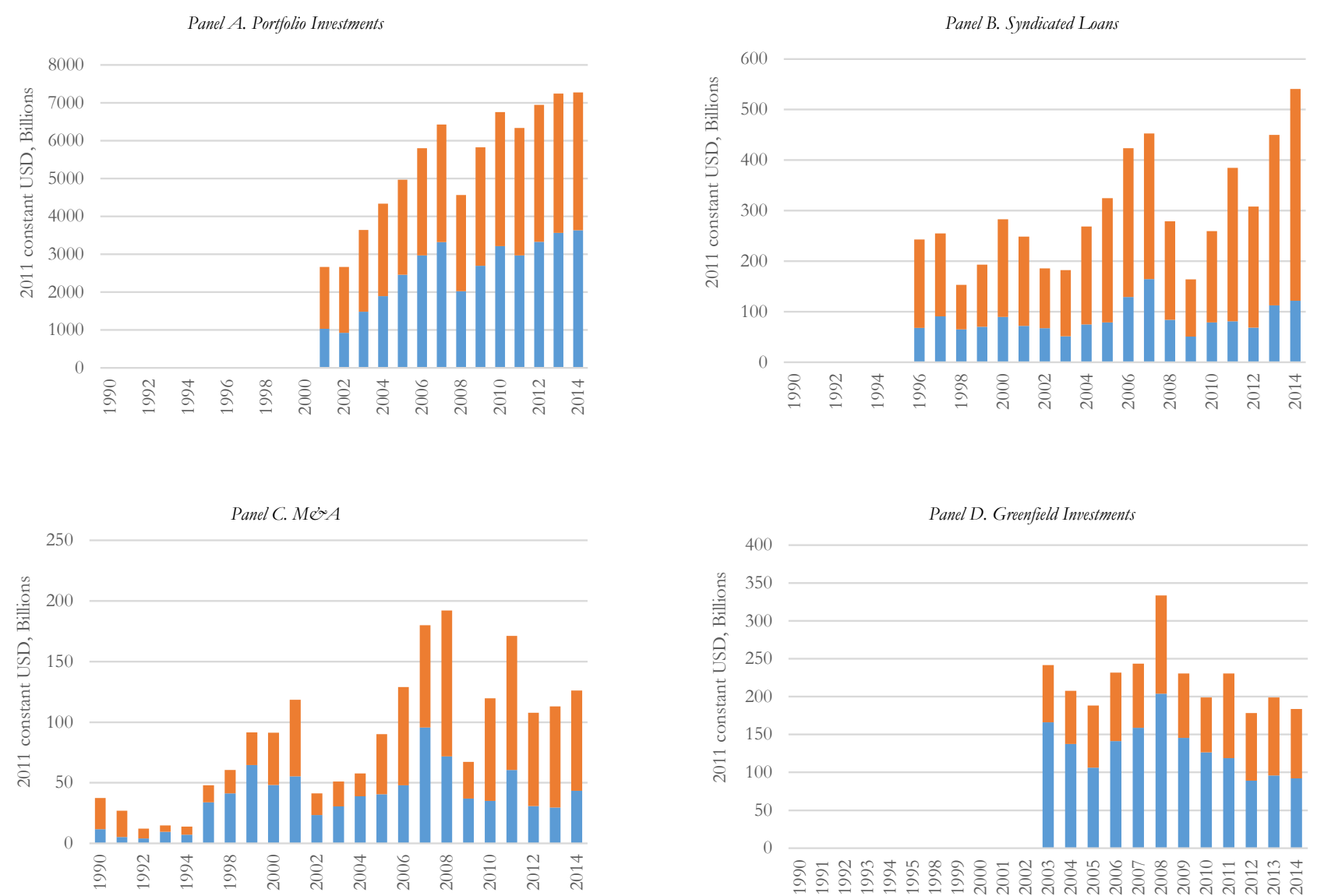

mAP as Destination =EAP as Source

This figure shows the value of financial investments to EAP economies from the rest of the world (EAP as a destination of foreign investments) and from EAP economies to the rest of the world (EAP as a source of foreign investments). The graphs do not include EAP's intra-regional cross-border investments. 
Figure 2. EAP's Inter-regional Investment Shares by North and South Economies

Panel A. Portfolio Investments

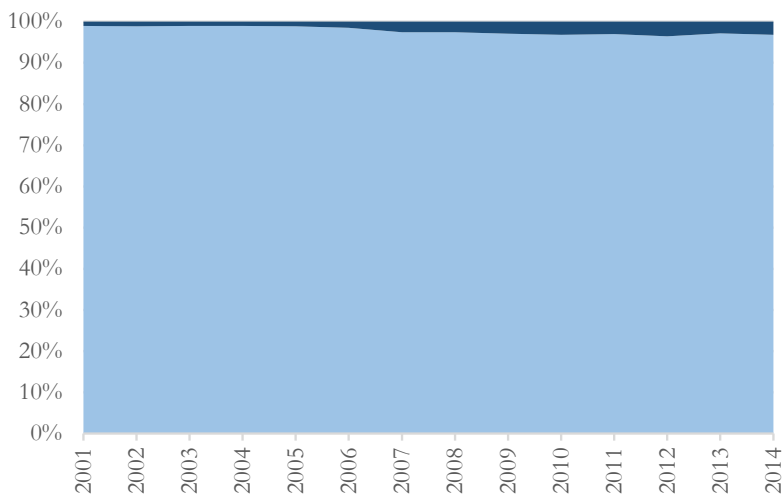

Panel C. M\&A

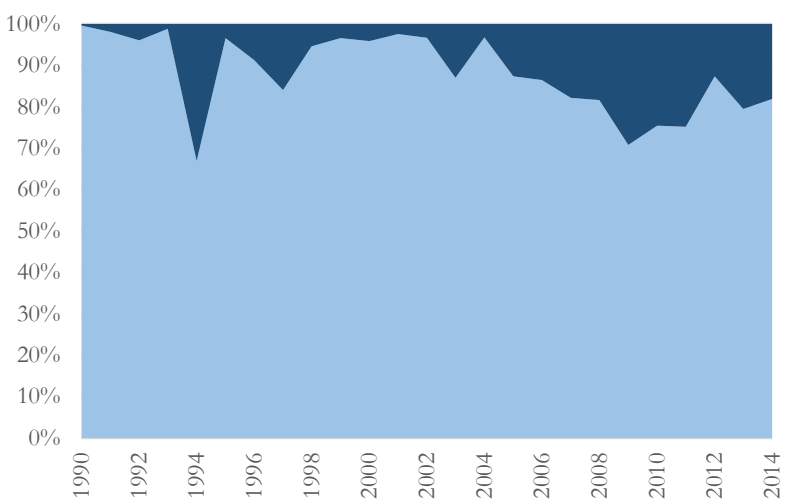

Panel B. Syndicated Loans

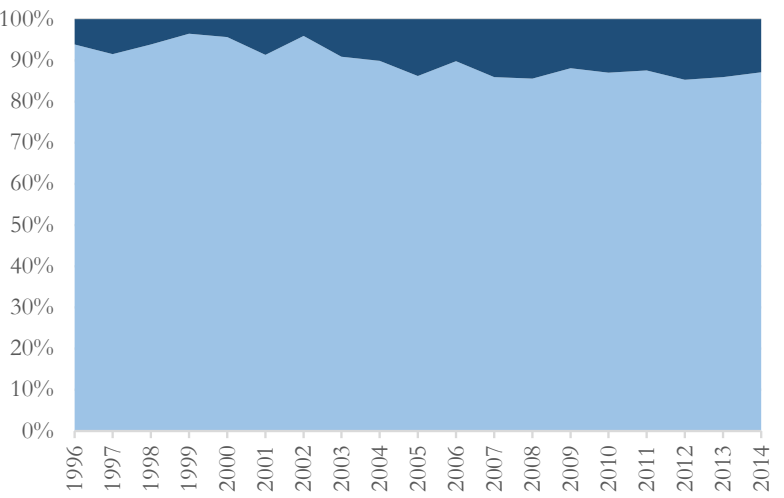

Panel D. Greenfield Investments

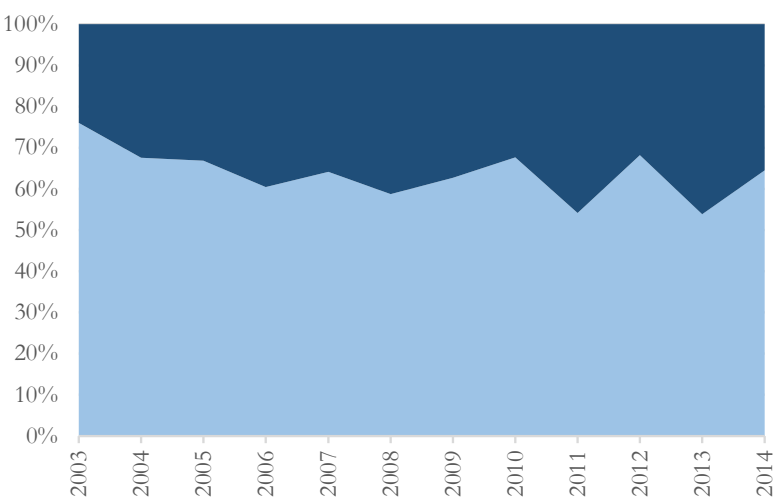

\section{North ESouth}

This figure shows the share of North and South economies in the value of EAP's inter-regional investments. The graphs do not include EAP's intra-regional cross-border investments. 

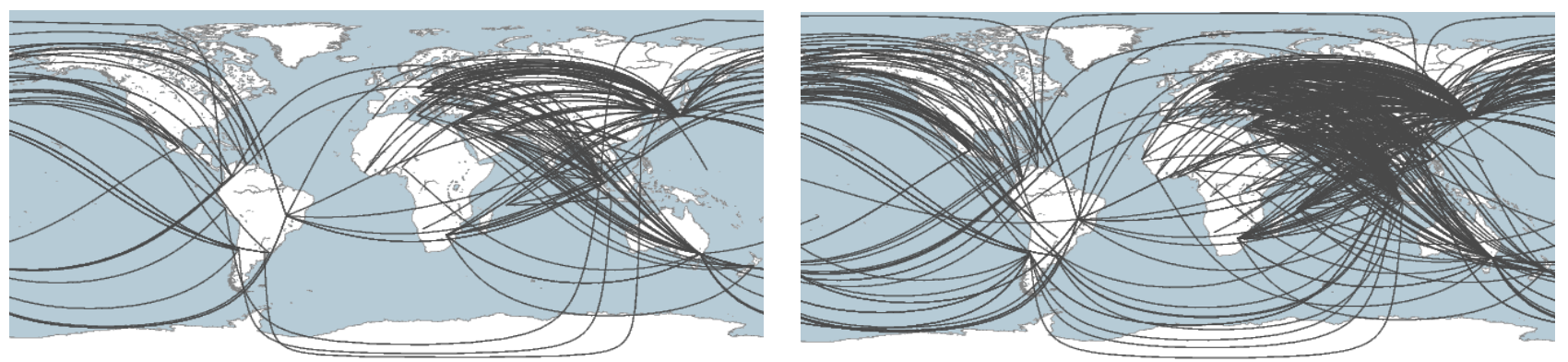

1996-1998

Panel B. Syndicated Loans
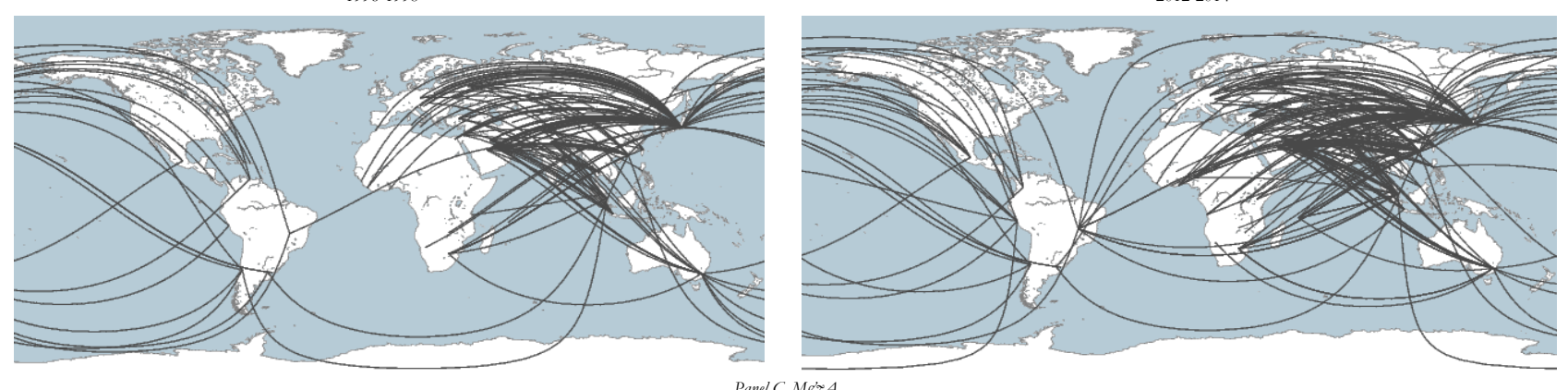

1990-1992
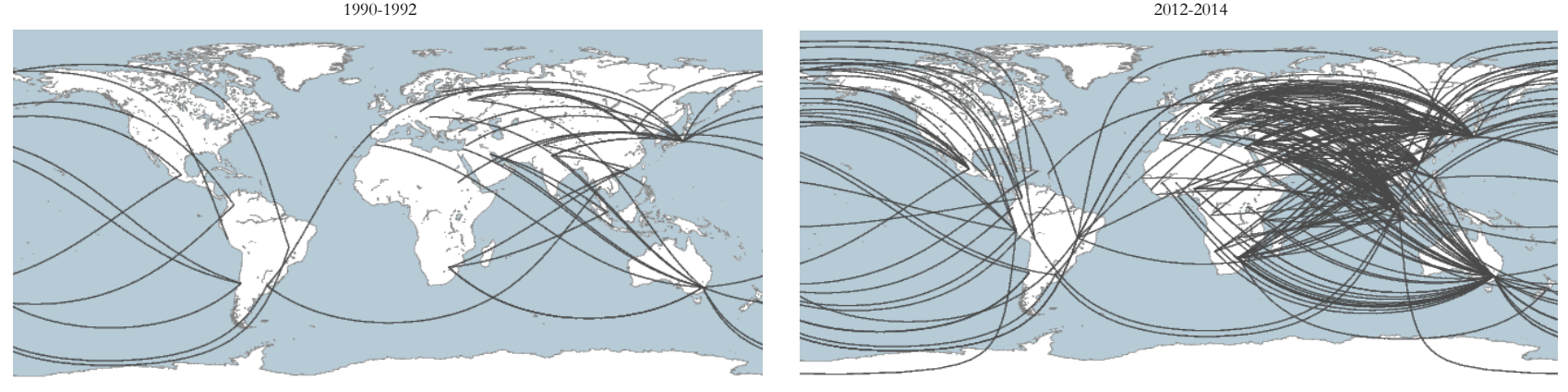

Panel D. Greenfield Investments

2003-2005
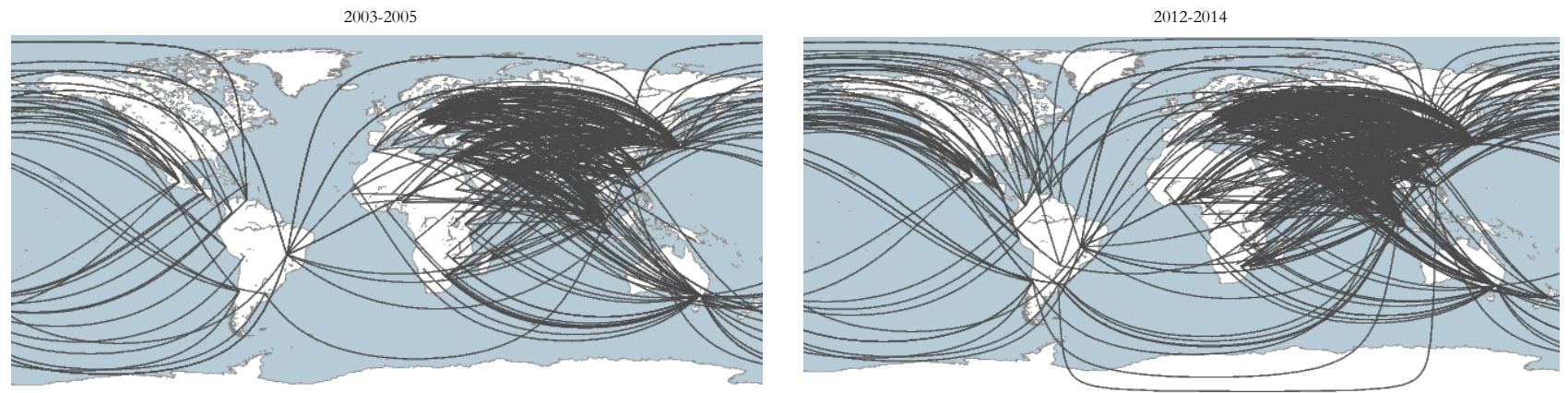

This figure shows the financial connectivity of EAP economies with South economies. Each line in the maps represents a positive cross-border investment between an EAP economy and a South economy. The graphs do not include EAP's intra-regional connections. 
Figure 4. EAP's Intra-regional Cross-border Financial Investments

Panel A. Portfolio Investments

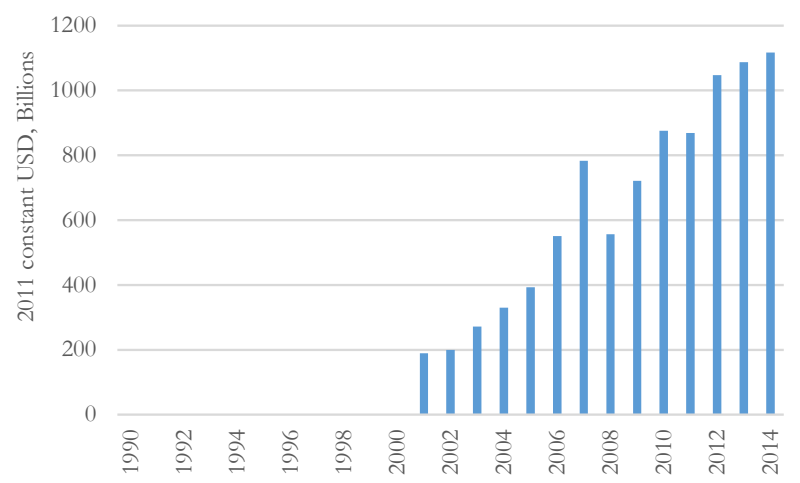

Panel C. M\&A

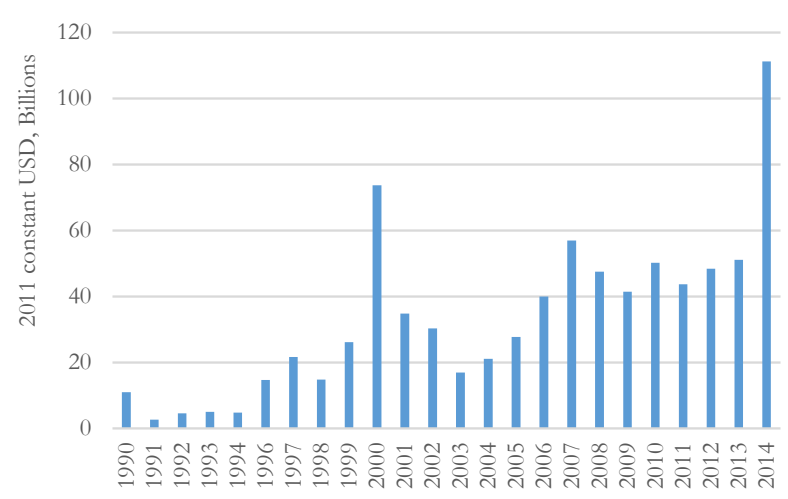

Panel B. Syndicated Loans

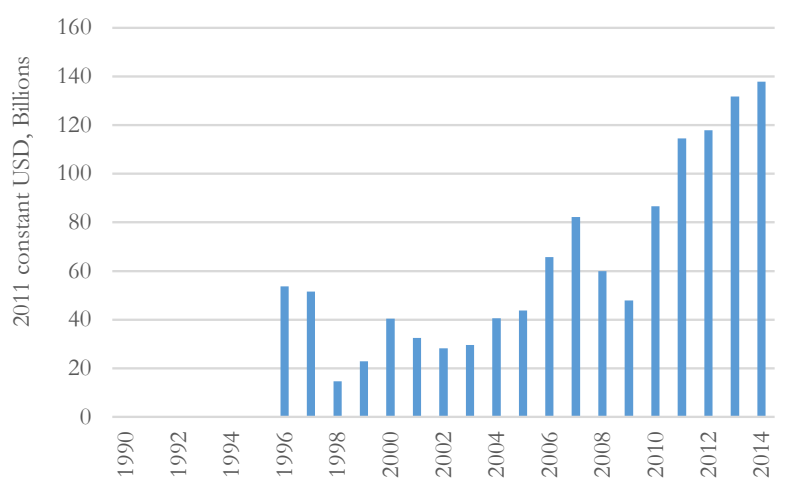

Panel D. Greenfield Investments

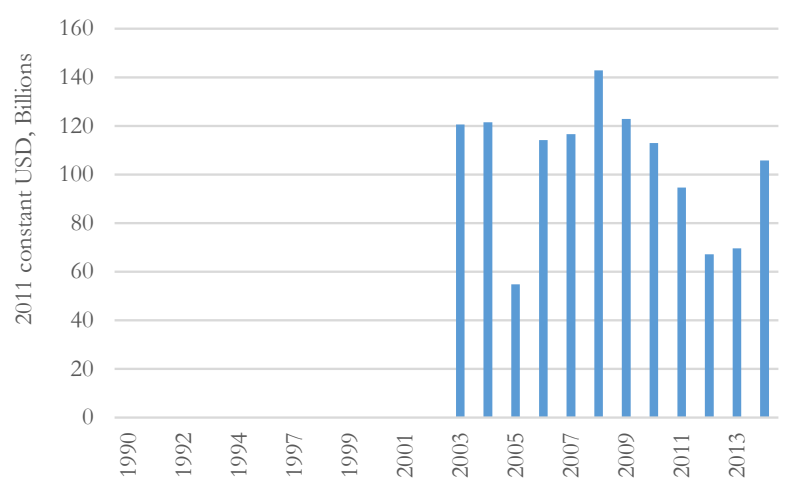


Figure 5. Cross-border Financial Connections within EAP
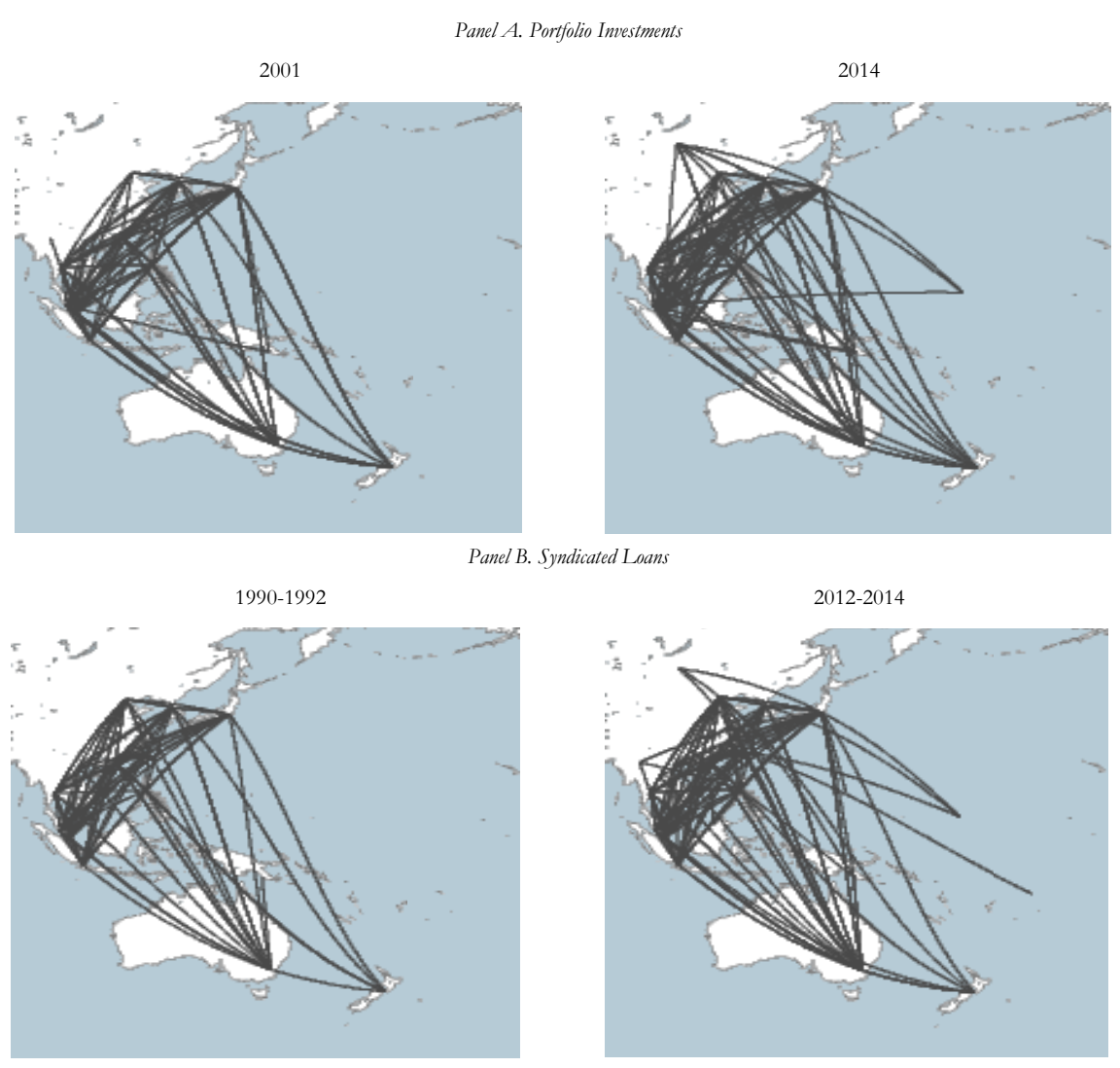

Panel C. M\&A
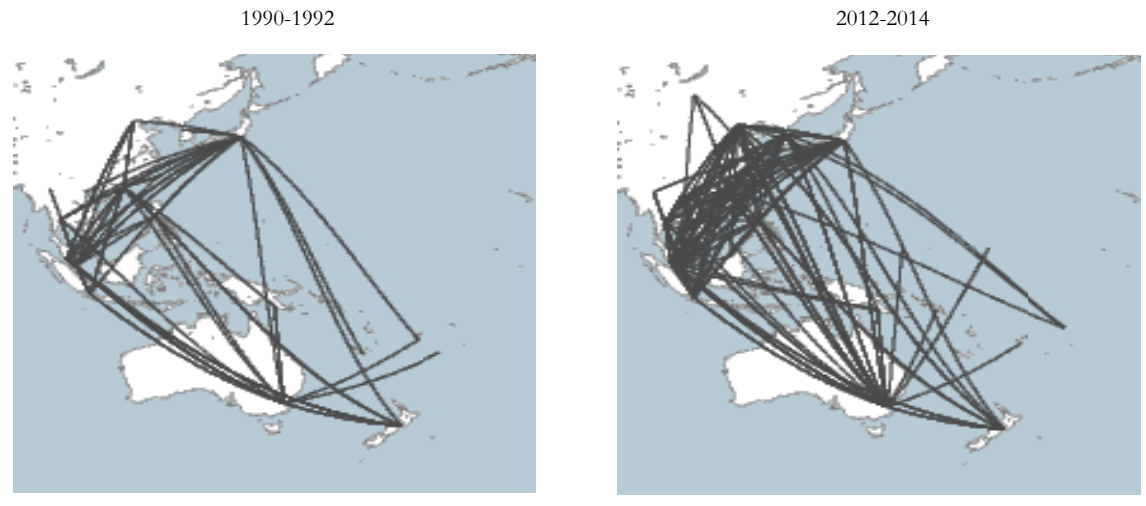

Panel D. Greenfield Investments
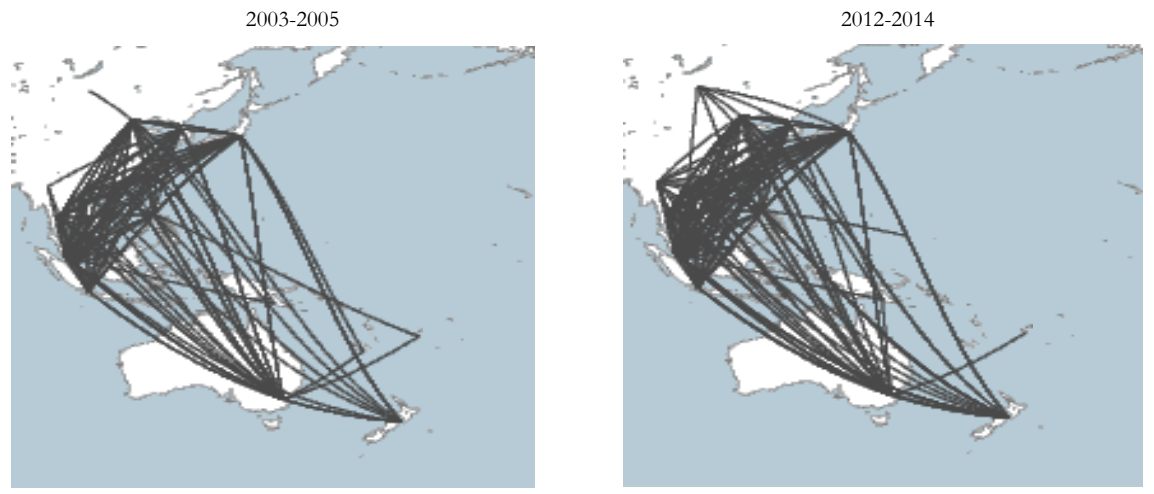

This figure shows the financial connectivity within the EAP region. Each line in the maps represents a positive cross-border investment between two EAP economies. 
Figure 6. Cross-border Investment Shares by North, South, and EAP Economies

Panel A. Portfolio Investments (2014)

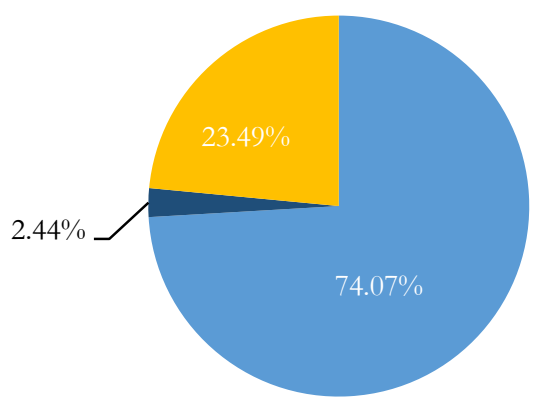

Panel C. M\&A (2003-2014)

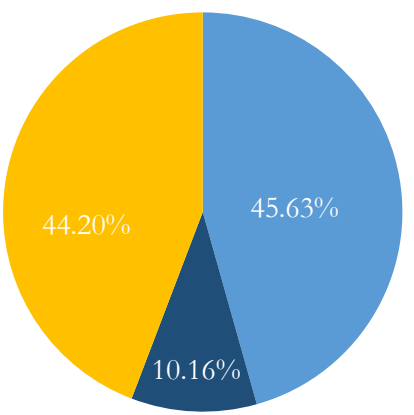

Panel B. Syndicated Loans (2003-2014)

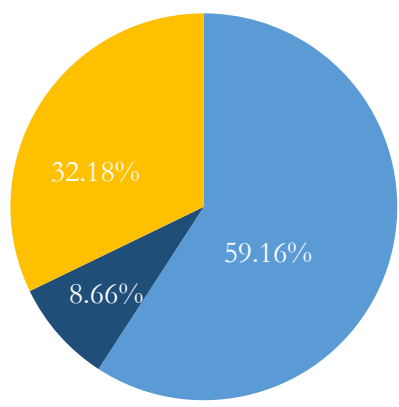

Panel D. Greenfield Investments (2003-2014)

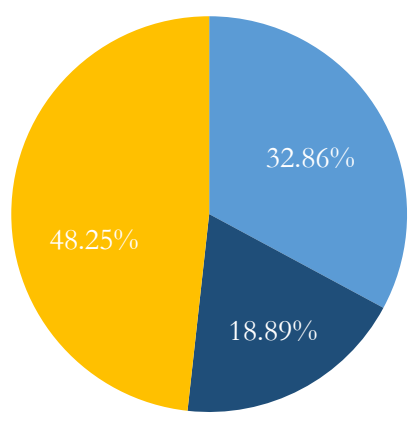

north a South EAP

This figure shows the share of North, South, and EAP economies in the total value of EAP's cross-border financial investments (considering investments with the North, the South, and with itself). 
Figure 7. Composition of EAP Cross-border Investments

Panel A. EAP's Inter-regional Investments

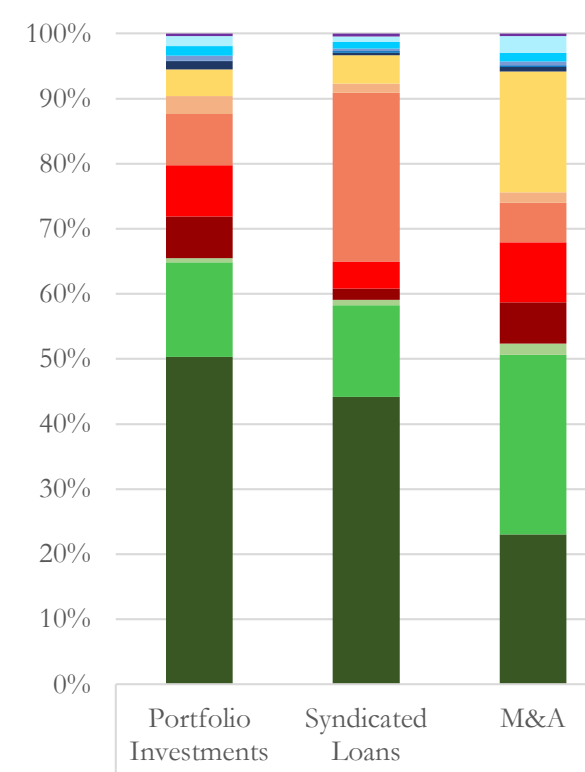

Intensive Margin

\section{- Japan}

- Hong Kong SAR (China)

- Philippines
- Australia

- Taiwan (China)

- Indonesia

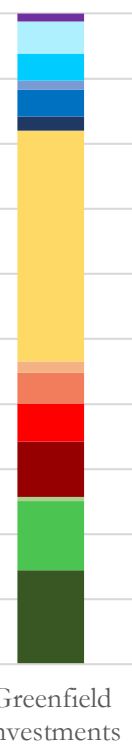

Greenfield
Investments

New Zealand

- China

- Malaysia

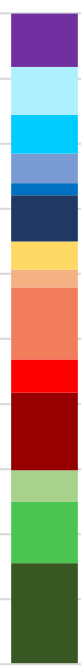

Portfolio Investments

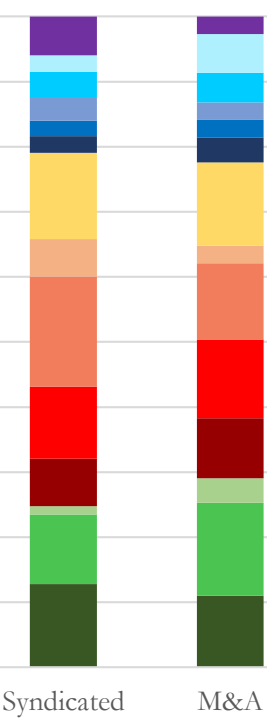

Loans

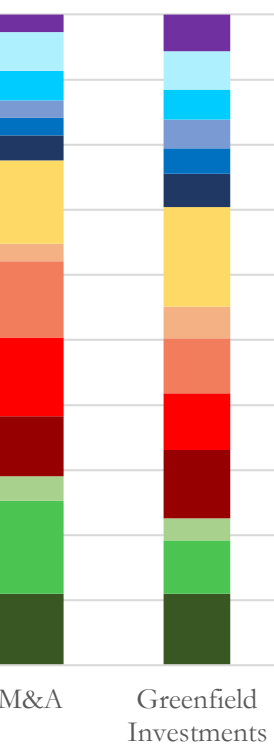

Extensive Margin

Panel B. EAP's Intra-regional Investments

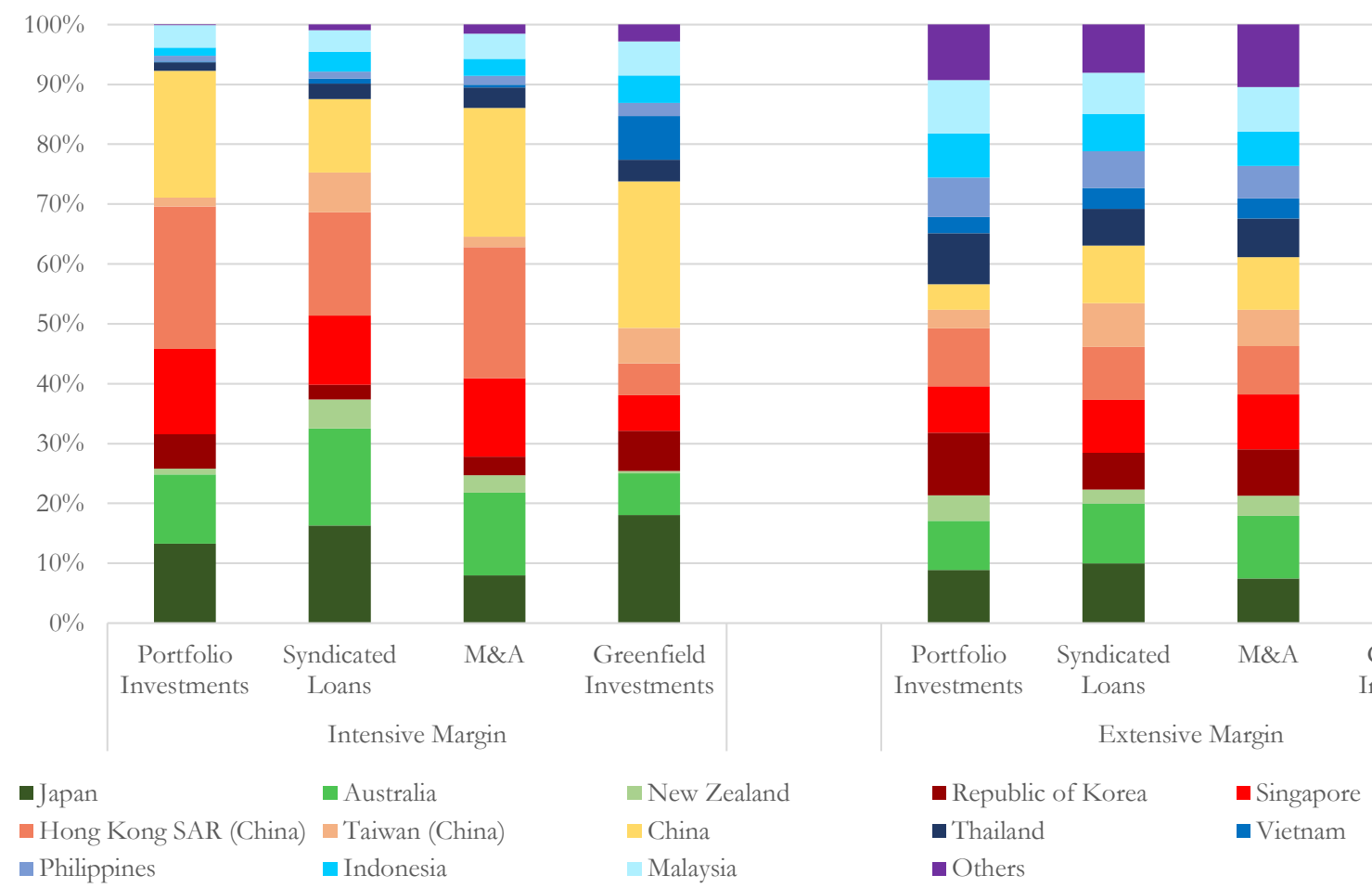

This figure shows the composition of EAP's inter-regional (Panel A) and intra-regional (Panel B) cross-border investments across EAP economies. For the intensive margin statistics, this figure shows the share of each economy (or group of economies) in the total value of EAP's cross-border investments between 2003 and 2014 , except for portfolio investments for which it considers only 2014. For the extensive margin statistics, this figure shows the share of each economy (or group of economies) in the number of EAP's cross-border connections between 2012 and 2014, except for portfolio investments for which it considers only 2014. Green and Red $=$ Developed EAP economies, Red $=$ NIEs, Yellow $=$ China, Blue $=$ ASEAN-5, and Purple $=$ Others. 
Table 1. A Gravity Model of EAP's Cross-border Financial Investments

\begin{tabular}{|c|c|c|c|c|c|c|c|c|c|c|c|c|}
\hline \multirow{2}{*}{$\begin{array}{l}\text { Type of Cross-border Investments } \\
\text { EAP-North }\end{array}$} & \multicolumn{3}{|c|}{ Portfolio Investments } & \multicolumn{3}{|c|}{ Syndicated Loans } & \multicolumn{3}{|c|}{ M\&A } & \multicolumn{3}{|c|}{ Greenfield Investments } \\
\hline & $9.510 * * *$ & $-12.297 * * *$ & $-11.867 * * *$ & $6.352 * * *$ & $-14.359 * * *$ & $-11.632 * * *$ & $4.582 * * *$ & $-16.456 * * *$ & $-10.673 * * *$ & $4.000 * * *$ & $-10.536 * * *$ & $-5.496 * * *$ \\
\hline & $(0.361)$ & $(3.176)$ & $(3.258)$ & $(0.365)$ & $(2.995)$ & $(3.238)$ & $(0.269)$ & $(2.233)$ & $(2.594)$ & $(0.291)$ & $(1.938)$ & $(1.962)$ \\
\hline \multirow[t]{2}{*}{ EAP-South } & 4.199 *** & $-14.988 * * *$ & $-14.483 * * *$ & $2.631 * * *$ & $-15.674 * * *$ & $-12.921 * * *$ & 1.155 *** & $-17.239 * * *$ & $-11.276 * * *$ & $2.729 * * *$ & $-9.789 * * *$ & $-4.686 * *$ \\
\hline & $(0.278)$ & $(3.145)$ & $(3.232)$ & $(0.175)$ & $(2.967)$ & $(3.208)$ & $(0.193)$ & $(2.192)$ & $(2.536)$ & $(0.120)$ & $(1.922)$ & $(1.940)$ \\
\hline \multirow[t]{2}{*}{ North-EAP } & $8.320 * * *$ & $-12.810 * * *$ & $-12.410 * * *$ & $4.873 * * *$ & $-15.284 * * *$ & $-12.524 * * *$ & $4.086 * * *$ & $-16.744 * * *$ & $-10.851 * * *$ & $5.070 * * *$ & $-9.216 * * *$ & $-4.042 * *$ \\
\hline & $(0.241)$ & (3.194) & $(3.241)$ & $(0.189)$ & $(3.021)$ & $(3.267)$ & $(0.242)$ & $(2.249)$ & $(2.578)$ & $(0.235)$ & $(1.916)$ & $(1.955)$ \\
\hline \multirow[t]{2}{*}{ South-EAP } & 3.296 *** & $-16.741 * * *$ & $-16.288 * * *$ & 0.124 & $-18.145 * * *$ & $-15.241 * * *$ & $0.503 *$ & $-18.171 * * *$ & $-12.219 * * *$ & 1.577 *** & $-10.678 * * *$ & $-5.426 * * *$ \\
\hline & $(0.272)$ & $(3.263)$ & $(3.365)$ & $(0.339)$ & $(2.994)$ & $(3.268)$ & $(0.275)$ & $(2.268)$ & $(2.655)$ & $(0.168)$ & $(1.912)$ & $(1.942)$ \\
\hline \multirow[t]{2}{*}{ EAP-EAP } & 7.651 *** & $-12.459 * * *$ & $-12.238 * * *$ & $4.958 * * *$ & $-14.131 * * *$ & $-11.734 * * *$ & $3.932 * * *$ & $-15.329 * * *$ & $-10.028 * * *$ & $4.874 * * *$ & $-8.902 * * *$ & $-4.268 * *$ \\
\hline & $(0.295)$ & $(2.935)$ & $(2.983)$ & $(0.190)$ & $(2.806)$ & $(2.994)$ & $(0.251)$ & $(2.104)$ & $(2.395)$ & $(0.199)$ & $(1.844)$ & $(1.836)$ \\
\hline \multirow[t]{2}{*}{ Log (Sender's GDP) } & & $0.836 * * *$ & $0.767 * * *$ & & $0.768 * * *$ & $0.516^{* * *}$ & & $0.702 * * *$ & $0.326 * * *$ & & 0.771 *** & $0.411 * * *$ \\
\hline & & $(0.087)$ & $(0.108)$ & & $(0.085)$ & $(0.117)$ & & $(0.045)$ & $(0.094)$ & & $(0.050)$ & $(0.067)$ \\
\hline \multirow[t]{2}{*}{ Log (Recipient's GDP) } & & $0.765 * * *$ & $0.688 * * *$ & & $0.681 * * *$ & $0.422 * * *$ & & $0.720 * * *$ & $0.412 * * *$ & & $0.610^{* * *}$ & $0.257 * * *$ \\
\hline & & $(0.063)$ & $(0.110)$ & & $(0.071)$ & $(0.124)$ & & $(0.051)$ & $(0.133)$ & & $(0.039)$ & $(0.066)$ \\
\hline \multirow[t]{2}{*}{ Log (Distance between Economies) } & & -0.139 & -0.041 & & 0.019 & 0.253 & & 0.120 & 0.199 & & $-0.456 * *$ & -0.269 \\
\hline & & $(0.272)$ & $(0.278)$ & & $(0.305)$ & $(0.298)$ & & $(0.212)$ & $(0.208)$ & & $(0.197)$ & $(0.187)$ \\
\hline \multirow[t]{2}{*}{ Difference in Time Zone } & & $0.086 * *$ & $0.066 *$ & & 0.050 & 0.035 & & $0.060 *$ & 0.053 & & 0.028 & 0.025 \\
\hline & & $(0.040)$ & $(0.040)$ & & $(0.076)$ & $(0.074)$ & & $(0.035)$ & $(0.033)$ & & $(0.036)$ & $(0.035)$ \\
\hline \multirow[t]{2}{*}{ Colony Dummy } & & 0.295 & 0.301 & & 0.597 & 0.660 & & 0.415 & 0.416 & & 0.032 & 0.226 \\
\hline & & $(0.341)$ & $(0.327)$ & & $(0.553)$ & $(0.514)$ & & $(0.303)$ & $(0.270)$ & & $(0.332)$ & $(0.275)$ \\
\hline \multirow[t]{2}{*}{ Common Legal Origin Dummy } & & 0.116 & 0.131 & & 0.568 & $0.635 *$ & & $0.604 * * *$ & $0.525 * *$ & & -0.197 & -0.296 \\
\hline & & $(0.215)$ & $(0.206)$ & & $(0.347)$ & $(0.336)$ & & $(0.218)$ & $(0.205)$ & & $(0.207)$ & $(0.198)$ \\
\hline \multirow[t]{2}{*}{ Common Language Dummy } & & 0.435 & 0.475 & & 0.542 & 0.429 & & $1.280 * * *$ & $1.421 * * *$ & & $0.892 * * *$ & $0.794 * *$ \\
\hline & & $(0.315)$ & $(0.303)$ & & $(0.487)$ & $(0.461)$ & & $(0.236)$ & $(0.238)$ & & $(0.320)$ & $(0.358)$ \\
\hline \multirow[t]{2}{*}{ Contiguity Dummy } & & $2.475 * * *$ & $2.439 * * *$ & & $1.030 * *$ & $0.821 *$ & & $1.732 * * *$ & $1.109 * *$ & & 0.340 & -0.085 \\
\hline & & $(0.541)$ & $(0.558)$ & & $(0.477)$ & $(0.464)$ & & $(0.381)$ & $(0.539)$ & & $(0.380)$ & $(0.451)$ \\
\hline \multirow[t]{2}{*}{ Log (Exports) } & & & 0.111 & & & 0.296 *** & & & $0.386 * * *$ & & & 0.400 *** \\
\hline & & & $(0.118)$ & & & $(0.113)$ & & & $(0.113)$ & & & $(0.062)$ \\
\hline \multicolumn{13}{|l|}{ Wald Tests: } \\
\hline 1. EAP-North vs. EAP-South & $5.312 * * *$ & $2.691 * * *$ & $2.616 * * *$ & $3.721 * * *$ & $1.316 * * *$ & $1.289 * * *$ & $3.428 * * *$ & $0.784 * * *$ & $0.602 * *$ & $1.271 * * *$ & $-0.747 * * *$ & $-0.810^{* * *}$ \\
\hline 2. North-EAP vs. South-EAP & $5.024 * * *$ & $3.931 * * *$ & $3.879 * * *$ & $4.749 * * *$ & $2.860 * * *$ & $2.717 * * *$ & $3.582 * * *$ & $1.427 * * *$ & $1.368 * * *$ & $3.493 * * *$ & $1.462 * * *$ & $1.384^{* * *}$ \\
\hline 3. EAP-North vs. EAP-EAP & $1.859 * * *$ & 0.163 & 0.371 & $1.394 * * *$ & -0.227 & 0.103 & $0.650 *$ & $-1.126 * * *$ & $-0.645 *$ & $-0.874 * *$ & $-1.635 * * *$ & $-1.229 * * *$ \\
\hline 4. North-EAP vs. EAP-EAP & $0.669 *$ & -0.351 & -0.172 & -0.086 & $-1.153 *$ & -0.790 & 0.154 & $-1.415 * * *$ & $-0.822 * *$ & 0.196 & -0.314 & 0.226 \\
\hline 5. EAP-South vs. EAP-EAP & $-3.452 * * *$ & $-2.529 * * *$ & $-2.245 * * *$ & $-2.327 * * *$ & $-1.543 * * *$ & $-1.187 * *$ & $-2.777 * * *$ & $-1.910 * * *$ & $-1.247 * * *$ & $-2.145 * * *$ & $-0.887 * * *$ & -0.419 \\
\hline 6. South-EAP vs. EAP-EAP & $-4.355 * * *$ & $-4.282 * * *$ & $-4.050 * * *$ & $-4.835 * * *$ & $-4.013 * * *$ & $-3.507 * * *$ & $-3.429 * * *$ & $-2.841 * * *$ & $-2.190 * * *$ & $-3.298 * * *$ & $-1.776 * * *$ & $-1.158^{* * *}$ \\
\hline Number of Observations & 49,379 & 37,524 & 29,737 & 81,396 & 61,971 & 41,213 & 128,135 & 85,665 & 47,684 & 118,656 & 84,994 & 49,550 \\
\hline R-Squared & 0.024 & 0.709 & 0.719 & 0.015 & 0.255 & 0.247 & 0.007 & 0.283 & 0.263 & 0.012 & 0.248 & 0.274 \\
\hline
\end{tabular}


Table 2. Intensive Margin Regressions Differences between Regional Dummy Coefficients

\begin{tabular}{|c|c|c|c|c|}
\hline \multirow[b]{2}{*}{ Type of Cross-border Investments: } & \multicolumn{4}{|c|}{ V alue of Cross-border Financial Investments } \\
\hline & $\begin{array}{c}\text { Portfolio } \\
\text { Investments }\end{array}$ & $\begin{array}{c}\text { Syndicated } \\
\text { Loans }\end{array}$ & $M \circlearrowleft A$ & $\begin{array}{l}\text { Greenfield } \\
\text { Investments }\end{array}$ \\
\hline \multicolumn{5}{|l|}{ Intra-regional Investments } \\
\hline (EAP-EAP) - (LAC-LAC) & $4.088 * * *$ & $2.457 * * *$ & $0.997 * *$ & $1.698 * * *$ \\
\hline (EAP-EAP) - (ECA-ECA) & $4.129 * * *$ & $2.299 * * *$ & $0.721 *$ & $0.735 * * *$ \\
\hline (EAP-EAP) - (SSA-SSA) & $1.901 * * *$ & 0.109 & $1.473 * * *$ & $0.640 *$ \\
\hline (EAP-EAP) - (SA-SA) & $7.318 * * *$ & $2.517 * * *$ & $3.222 * * *$ & $0.739 *$ \\
\hline (EAP-EAP) - (MENA-MENA) & $2.803 * * *$ & -0.024 & $1.159 * *$ & 0.292 \\
\hline (EAP-EAP) - (North-North) & $-1.192 * * *$ & -0.371 & -0.267 & $1.327 * * *$ \\
\hline Number of observations & 17,317 & 30,539 & 46,181 & 47,491 \\
\hline \multicolumn{5}{|l|}{ Investments Sent to the RoW } \\
\hline (EAP-RoW) - (LAC-RoW) & $2.125 * * *$ & $3.410 * * *$ & $1.240 * * *$ & $2.078 * * *$ \\
\hline (EAP-RoW) - (ECA-RoW) & $2.416 * * *$ & $4.713 * * *$ & $1.488 * * *$ & $1.216 * * *$ \\
\hline (EAP-RoW) - (SSA-RoW) & -0.431 & $2.891 * * *$ & $1.110 * * *$ & $1.005 * *$ \\
\hline (EAP-RoW) - (SA-RoW) & $6.284 * * *$ & $2.336 * * *$ & $1.258 * * *$ & 0.048 \\
\hline (EAP-RoW) - (MENA-RoW) & $1.127 * * *$ & $2.581 * * *$ & -0.042 & 0.216 \\
\hline (EAP-RoW) - (North-RoW) & 0.173 & $0.452 * *$ & 0.006 & $-0.723 * * *$ \\
\hline Number of observations & 110,959 & 182,088 & 256,903 & 259,862 \\
\hline \multicolumn{5}{|l|}{ Investments Received from the RoW } \\
\hline (RoW-EAP) - (RoW-LAC) & 0.189 & $-0.531 *$ & $-0.665 * * *$ & -0.178 \\
\hline (RoW-EAP) - (RoW-ECA) & 0.350 & $-1.356 * * *$ & $-0.664 * * *$ & 0.182 \\
\hline (RoW-EAP) - (RoW-SSA) & 0.502 & -0.863 & -0.438 & -0.155 \\
\hline (RoW-EAP) - (RoW-SA) & 0.274 & -0.078 & -0.063 & -0.181 \\
\hline (RoW-EAP) - (RoW-MENA) & $1.354 * * *$ & $-1.015 * *$ & 0.246 & 0.078 \\
\hline (RoW-EAP) - (RoW-North) & -0.428 & $-0.745 * *$ & $-0.313 *$ & $1.498 * * *$ \\
\hline Number of observations & 110,959 & 182,088 & 256,903 & 259,862 \\
\hline
\end{tabular}

This table shows the results of the benchmark regressions for the intensive margin of EAP's cross-border investments. The table reports separately the estimations associated with intra-regional (Panel A), outward (Panel B), and inward (Panel C) investments. The value of bilateral investments from a sender economy to a receiver economy is regressed on a set of intra-regional (Panel A) or inter-regional (Panels B and C) dummies. The regressions also include the following gravity controls: the logarithm of the sender and the receiver economies' GDPs, the logarithm of the geographic distance between the two economies, differences in time zones between the two economies, and a set of dummies indicating whether the two economies share a common language, whether they have a common legal origin, whether they have a common border, and whether the recipient (sender) is (or was) a colony of the sender (recipient). PPML estimations are reported. The table only reports the differences in the estimated coefficients and the associated significance of a two-tailed Wald test for these differences. The regressions benchmarking intra-regional (inter-regional) investments exclude inter-regional (intra-regional) investments. The sample period is 2003-2014. Standard errors are clustered at the bilateral level. *,**, and *** denote statistical significance at 10\%,5\%, and 1\%, respectively. EAP = East Asia and Pacific, LAC = Latin America and the Caribbean, ECA = Europe and Central Asia, SSA = Sub-Saharan Africa, SA = South Asia, MENA = Middle East and North Africa. RoW $=$ Rest of the World. 
Table 3. Extensive Margin Regressions Differences between Regional Dummy Coefficients

\begin{tabular}{|c|c|c|c|c|}
\hline \multirow[b]{2}{*}{ Type of Cross-border Investments: } & \multicolumn{4}{|c|}{ Dummy $=1$ if Cross-border Investments $>0$, Dummy $=0$ Otherwise } \\
\hline & $\begin{array}{c}\text { Portfolio } \\
\text { Investments }\end{array}$ & $\begin{array}{l}\text { Syndicated } \\
\text { Loans }\end{array}$ & $M \otimes A$ & $\begin{array}{l}\text { Greenfield } \\
\text { Investments }\end{array}$ \\
\hline \multicolumn{5}{|l|}{ Intra-regional Investments } \\
\hline (EAP-EAP) - (LAC-LAC) & $0.169 * * *$ & $0.178 * * *$ & $0.137 * * *$ & $0.139 * * *$ \\
\hline (EAP-EAP) - (ECA-ECA) & $0.135 * * *$ & $0.215 * * *$ & $0.149 * * *$ & $0.130 * * *$ \\
\hline (EAP-EAP) - (SSA-SSA) & -0.048 & $0.078 * * *$ & $0.074 * * *$ & $0.051 * * *$ \\
\hline (EAP-EAP) - (SA-SA) & $0.319 * * *$ & $0.193 * * *$ & $0.196 * * *$ & $0.129 * * *$ \\
\hline (EAP-EAP) - (MENA-MENA) & $0.262 * * *$ & $0.140 * * *$ & $0.173 * * *$ & $0.127 * * *$ \\
\hline (EAP-EAP) - (North-North) & $-0.144 * * *$ & $-0.144 * * *$ & $-0.198 * * *$ & $-0.083 * * *$ \\
\hline Number of observations & 17,317 & 30,539 & 47,959 & 47,491 \\
\hline \multicolumn{5}{|l|}{ Investments Sent to the RoW } \\
\hline (EAP-RoW) - (LAC-RoW) & $0.031 * * *$ & $0.036 * * *$ & $0.029 * * *$ & $0.046 * * *$ \\
\hline (EAP-RoW) - (ECA-RoW) & 0.000 & $0.038 * * *$ & $0.021 * * *$ & $0.029 * * *$ \\
\hline (EAP-RoW) - (SSA-RoW) & $-0.154 * * *$ & $0.012 * * *$ & $0.011 * * *$ & $0.020 * * *$ \\
\hline (EAP-RoW) - (SA-RoW) & $0.117 * * *$ & $0.022 * * *$ & $0.014 * * *$ & $0.012 * *$ \\
\hline (EAP-RoW) - (MENA-RoW) & $-0.038 * * *$ & $0.014 * * *$ & $0.019 * * *$ & $0.032 * * *$ \\
\hline (EAP-RoW) - (North-RoW) & $-0.207 * * *$ & $-0.048 * * *$ & $-0.055 * * *$ & $-0.099 * * *$ \\
\hline Number of observations & 110,959 & 182,088 & 260,625 & 259,862 \\
\hline \multicolumn{5}{|l|}{ Investments Received from the RoW } \\
\hline (RoW-EAP) - (RoW-LAC) & $0.104 * * *$ & $0.027 * * *$ & $0.007 * *$ & $0.019 * * *$ \\
\hline (RoW-EAP) - (RoW-ECA) & $0.198 * * *$ & 0.001 & $-0.007 * *$ & 0.002 \\
\hline (RoW-EAP) - (RoW-SSA) & $0.241 * * *$ & $0.020 * * *$ & 0.004 & $0.018 * * *$ \\
\hline (RoW-EAP) - (RoW-SA) & $0.237 * * *$ & $0.015 * *$ & 0.005 & $0.012 * *$ \\
\hline (RoW-EAP) - (RoW-MENA) & $0.271 * * *$ & $0.022 * * *$ & $0.030 * * *$ & $0.025 * * *$ \\
\hline (RoW-EAP) - (RoW-North) & $-0.060 * * *$ & $0.039 * * *$ & $0.010 * *$ & $0.063 * * *$ \\
\hline Number of observations & 110,959 & 182,088 & 260,625 & 259,862 \\
\hline \multicolumn{5}{|c|}{$\begin{array}{l}\text { This table shows the results of the benchmark regressions for the extensive margin of EAP's cross-border investments. The table reports separately } \\
\text { the estimations associated with intra-regional (Panel A), outward (Panel B), and inward (Panel C) investments. The dependent variable is a dummy } \\
\text { that takes the value of } 1 \text { when there is a positive investment from a source economy to a receiver economy, and } 0 \text { otherwise. The independent } \\
\text { variables include a set of intra-regional (Panel A) or inter-regional (Panels B and C) dummies as well as the following gravity controls: the logarithm } \\
\text { of the sender and the receiver economies' GDPs, the logarithm of the geographic distance between the two economies, differences in time zones } \\
\text { between the two economies, and a set of dummies indicating whether the two economies share a common language, whether they have a common } \\
\text { legal origin, whether they have a common border, and whether the recipient (sender) is (or was) a colony of the sender (recipient). The table } \\
\text { reports the linear probability model estimations. The table only reports the differences in the estimated coefficients and the associated significance } \\
\text { of a two-tailed Wald test for these differences. The regressions benchmarking intra-regional (inter-regional) investments exclude inter-regional } \\
\text { (intra-regional) investments. The sample period is 2003-2014. Standard errors are clustered at the bilateral level. *, *, and *** denote statistical } \\
\text { significance at 10\%, } 5 \% \text {, and 1\%, respectively. EAP = East Asia and Pacific, LAC = Latin America and the Caribbean, ECA = Europe and Central } \\
\text { Asia, SSA = Sub-Saharan Africa, SA = South Asia, MENA = Middle East and North Africa. RoW = Rest of the World. }\end{array}$} \\
\hline
\end{tabular}


Appendix Table 1. Intensive Margin Regressions

Differences between Regional Trend Coefficients

\begin{tabular}{|c|c|c|c|c|}
\hline \multirow[b]{2}{*}{ Type of Cross-border Investments: } & \multicolumn{4}{|c|}{ Value of Cross-border Financial Investments } \\
\hline & $\begin{array}{c}\text { Portfolio } \\
\text { Investments }\end{array}$ & $\begin{array}{c}\text { Syndicated } \\
\text { Loans }\end{array}$ & $M \otimes A$ & $\begin{array}{l}\text { Greenfield } \\
\text { Investments }\end{array}$ \\
\hline \multicolumn{5}{|l|}{ Intra-regional Investments } \\
\hline (EAP-EAP) trend - (LAC-LAC) trend & 0.041 & 0.037 & 0.055 & -0.041 \\
\hline (EAP-EAP) trend - (ECA-ECA) trend & -0.038 & -0.018 & 0.064 & $0.071 * *$ \\
\hline (EAP-EAP) trend - (SSA-SSA) trend & -0.013 & $-0.130 * *$ & $0.206 * * *$ & $-0.156 * * *$ \\
\hline (EAP-EAP) trend - (SA-SA) trend & 0.064 & -0.183 & 0.067 & -0.024 \\
\hline (EAP-EAP) trend - (MENA-MENA) trend & 0.046 & $0.176 * * *$ & 0.085 & 0.041 \\
\hline (EAP-EAP) trend - (North-North) trend & 0.033 & $0.056 * *$ & $0.070 *$ & $-0.078 * * *$ \\
\hline Number of observations & 17,317 & 30,539 & 46,181 & 47,491 \\
\hline \multicolumn{5}{|l|}{ Investments Sent to the RoW } \\
\hline (EAP-RoW) trend - (LAC-RoW) trend & -0.036 & 0.017 & $0.144 *$ & 0.054 \\
\hline (EAP-RoW) trend - (ECA-RoW) trend & $-0.055 * *$ & -0.005 & 0.067 & 0.054 \\
\hline (EAP-RoW) trend - (SSA-RoW) trend & -0.023 & -0.001 & $0.116 *$ & 0.099 \\
\hline (EAP-RoW) trend - (SA-RoW) trend & -0.075 & -0.027 & 0.026 & 0.018 \\
\hline (EAP-RoW) trend - (MENA-RoW) trend & -0.004 & -0.046 & $0.140 * * *$ & 0.026 \\
\hline (EAP-RoW) trend - (North-RoW) trend & 0.001 & $0.069 * * *$ & 0.067 & $0.038 *$ \\
\hline Number of observations & 110,959 & 182,088 & 256,903 & 259,862 \\
\hline \multicolumn{5}{|l|}{ Investments Received from the RoW } \\
\hline (RoW-EAP) trend - (RoW-LAC) trend & $-0.035 * *$ & $0.049 * *$ & $-0.074 * *$ & $-0.062 * *$ \\
\hline (RoW-EAP) trend - (RoW-ECA) trend & -0.018 & $0.053 * * *$ & 0.018 & $0.032 *$ \\
\hline (RoW-EAP) trend - (RoW-SSA) trend & -0.025 & -0.025 & -0.013 & -0.010 \\
\hline (RoW-EAP) trend - (RoW-SA) trend & $-0.035 *$ & 0.011 & $-0.053 *$ & -0.012 \\
\hline (RoW-EAP) trend - (RoW-MENA) trend & -0.007 & $0.103 * * *$ & 0.008 & 0.028 \\
\hline (RoW-EAP) trend - (RoW-North) trend & -0.015 & $-0.045 *$ & -0.045 & $-0.076 * * *$ \\
\hline Number of observations & 110,959 & 182,088 & 256,903 & 259,862 \\
\hline \multicolumn{5}{|c|}{$\begin{array}{l}\text { This table shows the results of the benchmark regressions for the intensive margin of EAP's cross-border investments. The table reports separately } \\
\text { the estimations associated with intra-regional (Panel A), outward (Panel B), and inward (Panel C) investments. The value of bilateral investments } \\
\text { from a sender economy to a receiver economy is regressed on a set of intra-regional (Panel A) or inter-regional (Panels B and C) dummies and } \\
\text { their interactions with a time trend. The regressions also include the following gravity controls: the logarithm of the sender and the receiver } \\
\text { economies' GDPs, the logarithm of the geographic distance between the two economies, differences in time zones between the two economies, } \\
\text { and a set of dummies indicating whether the two economies share a common language, whether they have a common legal origin, whether they } \\
\text { have a common border, and whether the recipient (sender) is (or was) a colony of the sender (recipient). PPML estimations are reported. The } \\
\text { table only reports the differences in the estimated interacted coefficients and the associated significance of a two-tailed Wald test for these } \\
\text { differences. The regressions benchmarking intra-regional (inter-regional) investments exclude inter-regional (intra-regional) investments. The } \\
\text { sample period is 2003-2014. Standard errors are clustered at the bilateral level. *, **, and *** denote statistical significance at } 10 \%, 5 \% \text {, and } 1 \% \text {, } \\
\text { respectively. EAP = East Asia and Pacific, LAC = Latin America and the Caribbean, ECA = Europe and Central Asia, SSA = Sub-Saharan Africa, } \\
\text { SA = South Asia, MENA = Middle East and North Africa. RoW = Rest of the World. }\end{array}$} \\
\hline
\end{tabular}




\section{Appendix Table 2. Extensive Margin Regressions Differences between Regional Trend Coefficients}

\begin{tabular}{|c|c|c|c|c|}
\hline \multirow[b]{2}{*}{ Type of Cross-border Investments: } & \multicolumn{4}{|c|}{ Dummy $=1$ if Cross-border Investments $>0$, Dummy $=0$ Otherwise } \\
\hline & $\begin{array}{c}\text { Portfolio } \\
\text { Investments }\end{array}$ & $\begin{array}{c}\text { Syndicated } \\
\text { Loans }\end{array}$ & $M \nLeftarrow A$ & $\begin{array}{c}\text { Greenfield } \\
\text { Investments }\end{array}$ \\
\hline \multicolumn{5}{|l|}{ Intra-regional Investments } \\
\hline (EAP-EAP) trend - (LAC-LAC) trend & -0.004 & $0.003 * * *$ & -0.001 & $0.003 * *$ \\
\hline (EAP-EAP) trend - (ECA-ECA) trend & $-0.018 * * *$ & $0.008 * * *$ & $0.004 * * *$ & $0.011 * * *$ \\
\hline (EAP-EAP) trend - (SSA-SSA) trend & $-0.020 * * *$ & $0.004 * * *$ & $0.002 * *$ & $0.005 * * *$ \\
\hline (EAP-EAP) trend - (SA-SA) trend & -0.007 & 0.003 & $0.004 * *$ & $0.013 * * *$ \\
\hline (EAP-EAP) trend - (MENA-MENA) trend & -0.002 & $0.010 * * *$ & $-0.003 *$ & $0.005 * * *$ \\
\hline (EAP-EAP) trend - (North-North) trend & 0.001 & $0.007 * * *$ & 0.001 & 0.001 \\
\hline Number of observations & 17,317 & 30,539 & 47,959 & 47,491 \\
\hline \multicolumn{5}{|l|}{ Investments Sent to the RoW } \\
\hline (EAP-RoW) trend - (LAC-RoW) trend & $0.002 *$ & 0.000 & $0.002 * * *$ & $0.002 * * *$ \\
\hline (EAP-RoW) trend - (ECA-RoW) trend & $-0.005 * * *$ & $0.001 *$ & $0.002 * * *$ & $0.001 * * *$ \\
\hline (EAP-RoW) trend - (SSA-RoW) trend & $-0.010 * * *$ & $0.002 * * *$ & $0.002 * * *$ & $0.002 * * *$ \\
\hline (EAP-RoW) trend - (SA-RoW) trend & $-0.008 * * *$ & $0.002 * * *$ & $0.002 * * *$ & 0.000 \\
\hline (EAP-RoW) trend - (MENA-RoW) trend & -0.001 & 0.000 & $0.001 * * *$ & 0.000 \\
\hline (EAP-RoW) trend - (North-RoW) trend & -0.002 & $0.003 * * *$ & $0.001 * *$ & $-0.004 * * *$ \\
\hline Number of observations & 110,959 & 182,088 & 260,625 & 259,862 \\
\hline \multicolumn{5}{|l|}{ Investments Received from the RoW } \\
\hline (RoW-EAP) trend - (RoW-LAC) trend & 0.001 & $0.001 *$ & $-0.001 * * *$ & 0.000 \\
\hline (RoW-EAP) trend - (RoW-ECA) trend & -0.002 & $0.005 * * *$ & 0.000 & $0.003 * * *$ \\
\hline (RoW-EAP) trend - (RoW-SSA) trend & $0.002 *$ & 0.000 & 0.000 & $0.001 * * *$ \\
\hline (RoW-EAP) trend - (RoW-SA) trend & $0.003 *$ & $0.001 * *$ & 0.000 & $0.001 * *$ \\
\hline (RoW-EAP) trend - (RoW-MENA) trend & $-0.003 * *$ & $0.004 * * *$ & $-0.001 * * *$ & $0.001 * * *$ \\
\hline (RoW-EAP) trend - (RoW-North) trend & $0.003 *$ & $-0.002 * * *$ & $-0.003 * * *$ & -0.001 \\
\hline Number of observations & 110,959 & 182,088 & 260,625 & 259,862 \\
\hline
\end{tabular}

This table shows the results of the benchmark regressions for the extensive margin of EAP's cross-border investments. The table reports separately the estimations associated with intra-regional (Panel A), outward (Panel B), and inward (Panel C) investments. The dependent variable is a dummy that takes the value of 1 when there is a positive investment from a source economy to a receiver economy, and 0 otherwise. The independent variables include a set of intra-regional (Panel A) or inter-regional (Panels B and C) dummies and their interactions with a time trend as well as the following gravity controls: the logarithm of the sender and the receiver economies' GDPs, the logarithm of the geographic distance between the two economies, differences in time zones between the two economies, and a set of dummies indicating whether the two economies share a common language, whether they have a common legal origin, whether they have a common border, and whether the recipient (sender) is (or was) a colony of the sender (recipient). The table reports the linear probability model estimations. The table only reports the differences in the estimated interacted coefficients and the associated significance of a two-tailed Wald test for these differences. The regressions benchmarking intra-regional (inter-regional) investments exclude inter-regional (intra-regional) investments. The sample period is 2003-2014. Standard errors are clustered at the bilateral level. *, **, and $* * *$ denote statistical significance at 10\%,5\%, and 1\%, respectively. EAP = East Asia and Pacific, LAC $=$ Latin America and the Caribbean, ECA = Europe and Central Asia, SSA = Sub-Saharan Africa, SA = South Asia, MENA = Middle East and North Africa. RoW $=$ Rest of the World. 